\title{
Középsô-triász dolomitok képződésének története és töréses deformációja a Szegedi-medence területén
}

\author{
GARAguly István*, RAucsiK Béla, VARGA Andrea, Schubert Félix \\ Szegedi Tudományegyetem, Ásványtani, Geokémiai és Kőzettani Tanszék, 6722 Szeged Egyetem u. 2-6. \\ *levelezô szerző, e-mail: garagulyistvan@ gmail.com
}

\section{Diagenetic and brittle deformation history of Middle Triassic dolomites in the Szeged Basin, Southeast Hungary}

Abstract

The Pannonian Basin consists of several deep sub-basins separated by uplifted basement highs. One of these subbasins is the Szeged Basin. A significant part of its pre-Cenozoic basement comprises Triassic dolomite rocks. In numerous cases these carbonates are good hydrocarbon reservoirs and hydrocarbon production is significant in this region of Hungary. Nonetheless, the detailed petrology of the Triassic reservoir rocks has not been investigated for decades. This study attempts to reconstruct the formation and brittle deformation history of the studied reservoir rocks belonging dominantly to the Szeged Dolomite Formation — using petrographic observations including fluorescence and cathodoluminescence microscopy. The investigations were performed on core samples collected from wells in the western part of the Szeged Basin. The aforementioned investigations reveal that the Triassic dolostones have been noticeably altered by several brittle deformation and cementation events. The original depositional environment can be reconstructed only for samples exhibiting a relic texture after dolomitization and which were affected by slight fragmentation. The formation of most of the examined sediments occurred in a shallow water marine environment with depositional conditions ranging from peritidal to subtidal.

After the deposition and the early near-surface diagenesis, an extensional regime began and the subsidence continued during the Jurassic-to-Early Cretaceous interval, while the studied succession reached the deep-burial zone. During this period the rock bodies were completely dolomitized by fabric-preserving and fabric-destructive processes. Differences among the observed dolomite fabrics suggest multiple dolomitization episodes. The main dolomitization events were followed by the formation of porphyrotopic, sucrosic and saddle dolomite under intermediate or deep burial conditions. During the Middle Miocene, the Triassic rocks were uplifted and subaerially exposed and this is indicated by abrasional sediments. De-dolomization could have been connected to this uplifting phase. The formation of a fluorescent sparry dolomite generation and bituminous veins seems to be related to the Neogene extensional regime and deformation. Remnants of organic matter (hydrocarbon inclusions and bituminous veins) suggest the occurrence of multiphase migration events. Recognition of the different hydrocarbon migration phases could provide the basis for the analysis of their relationship to the depositional, diagenetic and tectonic processes, and subsequent stages of the evolution of the basin.

Keywords: Szeged Basin, Szeged Dolomite Formation, Saddle dolomite, diagenetic history, fluid migration

Összefoglalás

A Pannon-medence aljzatának egyik részmedencéje a Szegedi-medence, mely szénhidrogén-földtani szempontból hazánk egyik kiemelt fontosságú területe. A prekainozoos aljzat legelterjedtebb mezozoos képződményei a középsőtriász dolomitok, melyek fontos szerepet töltenek be a terület szénhidrogén-rendszerének felépítésében. Jelen tanulmány célja, hogy az évtizedek óta nem vizsgált képződmények képződéséről és deformációtörténetéről új, korszerú leírást nyújtson. Értelmezésünket általános petrográfiai leírásra, fluoreszcens és katódlumineszcens vizsgálati módszerekre, valamint a területról szóló szakirodalomra alapozzuk.

A vizsgált anisusi képződmények változatos partszegélyi, sekélytengeri környezetben ülepedtek le. Ezek a leülepedést követő süllyedés következtében, a sekély és közepes betemetődés után, a kora-krétára juthattak a mély betemetődési diagenezis zónájába. Ezen zónákban a képződmények feltehetően többfázisú, részben szövetmegőrző, részben szövetromboló dolomitosodási folyamatokon mentek keresztül. A petrográfiai alapon elkülönített dolomittípusok közül közepes vagy mély betemetôdési környezetet jeleznek a porfirotópos és cukorszövetú dolomitok, valamint a póruskitöltô nyeregdolomit, de ezek szerepe alárendelt a korábbi dolomitosodási folyamatokhoz viszonyítva. 
A középsô-miocént megelőzően a kőzeteket többször is töréses deformáció érte, melynek hatására breccsa, ezt követôen pedig üreg- és repedéskitöltő nyeregdolomit képződött. A nyeregdolomit kristályai több esetben kőolajtartalmú fluidumzárványokat csapdáztak. A dolomittestek felszínközeli helyzetét középső-miocén, abráziósparti környezetben leülepedett fedőkőzetek jelzik, továbbá dedolomitosodás is kapcsolódhat ehhez a szakaszhoz. A Pannonmedence kialakulásával párhuzamos süllyedés és eltemetődés hatására a képződmények ismét nagy mélységbe kerültek, mely során újabb töréses deformáció és cementáció folyt. A legfiatalabb repedéskitöltő ásványegyüttest fluoreszcens tulajdonságú dolomit, valamint pirit és szilárd bitumen alkotja.

A vizsgált dolomitok többfázisú diagenezis- és deformációtörténetéhez többfázisú szénhidrogén-migrációs események kapcsolhatóak, melyek pontosabb megismerése és elhelyezése a medence fejlődéstörténetében kulcsfontosságú. Az erôsen átalakult nyeregdolomit tartalmú minták további vizsgálata rezervoárgeológiai szempontból a jövőben szintén fontos feladat.

Tárgyszavak: Szegedi-medence, Szegedi Dolomit Formáció, nyeregdolomit, diagenezistörténet, fluidummigráció

\section{Bevezetés}

A Pannon-medence DK-i részének egyik alaphegységi szinten jól elkülöníthetô neogén szerkezeti egysége a Szegedi-medence. A medence - és közvetlen környezete hazánk legjelentősebb szénhidrogén-termelő területe (Horváth I. 2003, Horváth Z. \& Maros 2012), melyen belül a szénhidrogénrendszer elemeinek (anyakőzetek, migrációs útvonalak, tárolókőzetek, csapdák, záró képződmények) megismerése kulcsfontosságú. A Szegedi-medence területén a repedezett metamorfit, dolomit, bazalt, valamint változó kifejlődésú mátrixporozitású üledékes kőzetek egyaránt megtalálhatók a szénhidrogéntelepek tároló kőzeteként (Horváth Z. \& MAROs 2012, Kiss et al. 2015). A középsố-triász sekélytengeri karbonátok közül a Szegedi Dolomit Formációba sorolt litológiai egység jelentőségét kell kiemelni (BÉRCZINÉ MAKK 1986), mely döntően repedezett tárolók felépítésében vesz részt. A Szegedi Dolomit Formáció eddigi egyetlen, átfogó diagenezistörténeti vizsgálatát HoRváTH A. (1990) végezte. Mivel a képződményról - a medence szénhidrogén-rendszerében betöltött kulcsfontosságú szerepe ellenére - csak igen kisszámú és több évtizedes szakirodalom áll rendelkezésre, ezért indokolt annak komplex reambulációs vizsgálata.

Jelen tanulmányunk az NKFI (OTKA) K 108375 kutatáshoz — projektcím: Az Algyőii-aljzatmagaslat és a környező mélymedencék (Dorozsmai-medence, Makói-árok) integrált diagenezis-történeti és fluidumevolúciós rekonstrukciója - kapcsolódik. Ennek a célja a preneogén aljzatkőzetek (kristályos képződmények, feltételezett karbon breccsa, triász homokkô, márga és dolomit), valamint azok repedéskitöltő fázisainak kutatása. Munkánkban a Szegedimedencében mélyült fúrásokból választottunk ki a Szegedi Dolomit Formációba sorolt kőzeteket komplex vizsgálatra (ásványos összetételi és szöveti vizsgálatok, zárványpetrográfia, mikrotermometria, stabilizotóp-geokémia). Ennek első lépéseként adjuk közre a jelen tanulmányt, melynek az a célja, hogy az Üllés és Mórahalom környéki mélyfúrásokból származó középsố-triász karbonátkôzetekről, illetve az azokat harántoló karbonátos érkitöltésekrôl új, korszerú dokumentációval ellátott leírást adjon, továbbá összevesse azokat HoRvátH A. (1990) korábbi megállapításaival. E kőzetek, illetve azok töréses deformációjának részletes petrográfiai vizsgálatát az indokolja, hogy az Alföld aljzatában nagy területen ismert dolomitkőzetek képződési körülményeirôl rendkívül hiányosak az ismeretek. A makroszkópos és polarizációs mikroszkópos vizsgálatok alapján felvázolt betemetôdéstörténet kiindulási alapul szolgál e kôzetek diagenezistörténeti modelljének pontosításához.

\section{Földtani háttér}

A jelenleg érvényben lévő nagyszerkezeti beosztás szerint (HAAS et al. 2010) a Szegedi-medence a Tiszaifőegység aljzatának egyik részmedencéje, melyet döntően a Békés-Codrui-zóna gyưrt takarós szerkezete alkot, ami a terület ÉNy-i részén a Villány-Bihari-zónára tolódott. A terület aljzatszerkezetét döntően ÉNy-i vergenciájú mezozoos kompressziós szerkezetek (pikkelyek, áttolódások) és azokra merőleges, ÉNy-DK-i csapású kainozoos normálvetók határozzák meg. Az elmúlt években több olyan értelmezés jelent meg a nemzetközi szakirodalomban (SCHMID et al. 2008, Matenco \& Radivojević 2012), amelyek a Szegedi-medencét keletről határoló Algyői-aljzatmagaslatot a Kisbihari-zóna részeként kezelik (1. ábra).

Több publikáció (PigotT \& RAdivojević 2010, RAdivojević et al. 2010, MATENCO \& RADIVOJEvić 2012) a fiatal szerkezeti mozgások jelentőségére hívja fel a figyelmet. A korábbi modellekhez hasonlóan ezek a tanulmányok a takaróképződést követő laposszögú normálvetôk szerepét emelik ki a szerkezetalakulás legjelentősebb bélyegeiként, amelyek ún. aljzati magkomplexumok kialakulásához vezettek (pl. TARI et al. 1999, M. TóTH 2008). Megállapításaik szerint a Szegedi-medence egy nyugati irányba dőlő normálvető fejlődésével egyidejúleg kialakult aszimmetrikus félárokként fogható fel.

A 2500-7000 m vastag neogén üledéksorral kitöltött medence preneogén aljzatát variszkuszi metamorfitok, perm törmelékes és vulkáni kôzetek, germán jellegú alsótriász sziliciklasztos összlet, valamint középső-triász platform fáciesû dolomitok alkotják. A területen fiatalabb mezozoos képződmények nem ismertek, az aljzatra jelentôs eróziós diszkordanciával középső-miocén durvatörmelékes rétegsor települ (HoRváth Z. \& MAROs 2012).

A Szegedi-medence legáltalánosabban elterjedt mezozoos képződménye a középső-triász sekélytengeri, sötétszürke, alsó harmadán erősen breccsásodott dolomit, mely a 

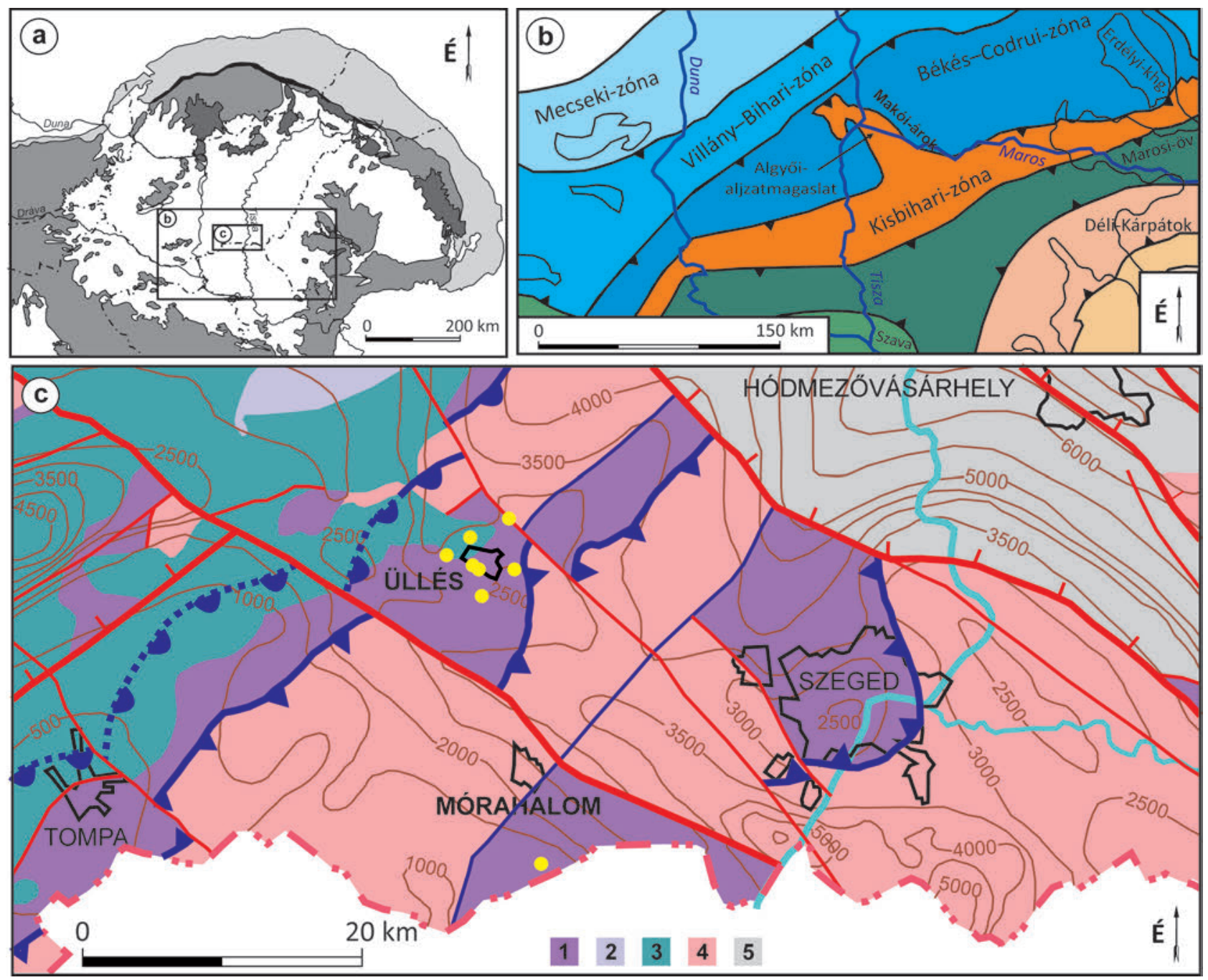

1. ábra. A mórahalmi és az üllési terület elhelyezkedése (a) a Pannon-medence felszíni és (b) szerkezeti (MATENCo \& RADIVoJEvić 2012, módosítva), valamint (c) a Szegedi-medence aljzatának földtani térképén (HAAs et al. 2010, módositva)

Jelkulcs (a): világosszürke: Alp-Kárpáti-flisöv; középszürke: Belső-alp-kárpáti egységek és Dinaridák; sötétszürke: Neogén mészalkáli vulkáni képződmények; fekete: Pienini-szirtöv Jelkulcs (c): 1) Középsỏ-triász sekélytengeri, sziliciklasztos és karbonátos kőzetek; 2) Alsó-triász folyóvízi és delta fáciesű, sziliciklasztos képződmények; 3) Jura és kréta képződmények: 4) Mezozoikumnál idősebb képződmények és metamorfitok; 5) Ismeretlen medencealjzat; Sárga kitöltött körök: mintázott fúrások

Figure 1. Location of the study area on the geologic (a) and structural (b) map of the Pannonian Basin (modified after MATENCO \& RADIVOJEVIĆ 2012), (c) Generalized geologic map of basement formations of the Szeged Basin (HAAS et al. 2010, modified)

Legend (a): light grey: Alpine-Carpathian flysch belt; medium grey: Inner Alpine - Carpathian Mountain belt and the Dinarides; dark grey: Neogene calc-alkaline volcanic rocks; black: Pieniny klippen belt

Legend (c): 1) Middle Triassic shallow marine siliciclastic and carbonate formations; 2) Lower Triassic siliciclastic formations of fluvial and delta facies; 3) Jurassic and Cretaceous formations, 4) Pre-Mesozoic and metamorphic complexes; 5) Unknown basement; Yellow filled circles: sampled wells

Szegedi Dolomit Formáció nevet viseli (1. ábra, c). Előfordulási területének jelentôs részén közvetlenül a kristályos aljzatra, néhol az alsó-triász összletre települ. Álvastagsága a lepusztulás mértékétól és a szegedi, valamint az üllési területen kimutatott rétegismétlődésektől függően 20-670 m között változik (BÉRCZINÉ MAKK 1986, BÉRCZINÉ MAKK et al. 2004). Fedőjében a Szegedi-medence területén mindenhol jelentôs eróziós diszkordanciával települ a neogén rétegsor.

A fedőképződmények közül meg kell említeni azokat a bizonytalan korú (középső-miocén vagy pannóniai) abráziós, parti képződményeket, melyek kőzetanyaga a környező alaphegységből származik, és kifejlődésüket tekintve analógok a Békési Konglomerátum Formációval. Ezek legnagyobb vastagságukat a szerkezeti magaslatok szárnyhelyze- tében érik el, míg a tetózónák és a mélyzónák irányában elvékonyodnak és kiékelődnek (JuHÁsz 1992, 1998).

\section{Kutatási elôzmények}

A Szegedi-medence területén a múlt század hatvanas éveitől kezdôdôen számos szénhidrogénkutató fúrás feltárta azt a sötétszürke dolomittípust, melyet a Szegedi Dolomit Formáció elnevezésú litosztratigráfiai egységbe sorolnak (BÉRCZINÉ MAKK 1986, 1998, BérCZINÉ MAKK et al. 2004).

A Szegedi Dolomit Formáció eddigi legátfogóbb diagenezistörténeti vizsgálatát HoRvÁtH A. (1990) végezte üllési, ruzsai, forráskúti és szegedi fúrásokból származó mintákon. Tanulmányában az üledékképződési környezet 
meghatározásához WILSON (1975) standard mikrofácies típusait vette alapul, és az így beazonosított mikrofácieseket helyezte el egy elméleti homoklinális rámpán READ (1985) modellje szerint. A következő áttekintố részben — a szöveghúség érdekében — valamennyi megnevezést HoRváTH A. (1990) munkájában szerepló módon, változtatás nélkül közöljük, még akkor is, ha az a ma elfogadott nevezéktannak már nem felel meg.

A sekélytengeri-partközeli régióban HoRváTH A. (1990) az árapályöv és lagúna környezetre jellemző mikrofáciesként azonosította a finoman laminált mudstone, peloid-alga bindstone és rétegzetlen mudstone típusokat. A sekélyvízi pad-komplexum és homokzátonyok jellemző képződményeként azonosította a bioklaszt-intraklaszt-peloid packstone és peloid grainstone mikrofácieseket, továbbá a mélyebb vízi, viharüledékeket tartalmazó középső rámpa képződményekhez sorolta a bioklaszt wackestone-mudstone mikrofáciesú mintákat.

Az üledékképződési környezet meghatározását követően HoRvátH A. (1990) felvázolta a képződmény eltemetôdésének történetét, amelyben három, átkristályosodással létrejött dolomittípust írt le SiBLEY \& GREGG (1987) dolomitszövetre vonatkozó nevezéktanát alkalmazva. Értelmezése szerint az első dolomitosodással járó esemény a sekély eltemetôdés zónájában érte a képződményt, ekkor „unimodális, aprószemcsés $(0,01 \mathrm{~mm})$, nem-planáris szövetú dolomit" képződött. A leírás szerint a második generációs dolomittípus ,unimodális, változó szemcsenagyságú $(0,01-$ $0,1 \mathrm{~mm}$ ) általában planáris szövetû dolomit, gyakran CCCR jelleggel (cloudy-centered, clear-rimmed), azaz a kristályokban egy zavaros magot tiszta továbbnövekedési köpeny vesz körül”. Az elsố két dolomitosodási-átkristályosodási fázison kívül egy harmadik, mélyeltemetődési dolomittípust is megkülönböztetett, amit ,polimodális, változó szemcsenagyságú $(0,01-1 \mathrm{~mm})$, nem planáris, gyakran poikilites szövetú dolomit"-ként jellemzett, azonban ez csak a Forráskút-10 fúrásban, ,erôsen átdolgozott breccsákban” fordult elő.

A Szegedi Dolomit Formáció eltemetôdés-történetéhez kapcsolódóan HoRvátH A. (1990) négy „hasadékkitöltési” és breccsásodási fázist különített el. A töréses deformációval és cementációval járó események közül az elsố repedésgenerációba sorolta azokat a korai diagenetikus eredetú, pátos, mikropátos, nem fluoreszcens dolomitereket, melyeket a mélyebb eltemetődés során végbemenő dolomitosodási fázisok átkristályosítottak. Megállapításai szerint ezt követően intenzív töréses deformáció következett, mely breccsásodással járt. A harmadik generációs hasadékkitöltési fázisba sorolta a zónásan fluoreszcens, unduláló kioltású nyeregdolomit típust, mely mindig megelőzi az erősen fluoreszcens negyedik fázist. A legfiatalabb, negyedik generációs hasadékkitöltési csoportba egy erősen fluoreszkáló, finomszemcsés, helyenként zónásságot mutató dolomittípust sorolt.

A tanulmány azonban leszögezi, hogy a fentieken kívül több lokális jellegú, nehezen besorolható hasadékkitöltési fázis lehetett, és a sztilolitképződés is több fázisban zajlott. HoRváth A. (1990) véleménye szerint a nyeregdolomit- típus a hasadékkitöltő fázisokon kívül póruskitöltésiátkristályosodási folyamatok eredményeként szintén megjelenik.

\section{Minták és vizsgálati módszerek}

A Szegedi-medence területén, valamint annak közvetlen környezetében a középső-triász képződményeknek négy fő előfordulása ismert, melyeket aljzatmagaslatok kutatásához kapcsolódóan tártak fel (1. ábra). Eddigi kutatásaink során a medence nyugati részén található üllési és mórahalmi előfordulásokból származó mintákat vizsgáltunk. Jelen tanulmány összesen 20 üllési és 7 mórahalmi mélyfúrásból származó magminta vizsgálati eredményein alapul. Az üllési minták jellemzően 2300-3300 méter, míg a mórahalmiak 1200-1400 méteres mélységből származnak, ami a rendkívül tagolt aljzatmorfológia következménye. A fúrások neveit a MOL Nyrt.-vel kötött együttmúködési megállapodásnak megfelelően nem közöljük, hozzávetőleges helyüket az 1. ábra „c” jelú térképe szemlélteti.

A mikropetrográfiai vizsgálatokat $30 \mu \mathrm{m}$ vastag, polírozott vékonycsiszolatokon végeztük. A különböző karbonáttípusok elkülönítése céljából a csiszolatokat Dicksonféle oldattal festettük meg (DicKson 1966). A dolomit szöveti nevezéktana MACHEL (2004) összefoglaló munkáján alapul, ami GregG \& Sibley (1984) és Sibley \& GREGG (1987), rendszerének kiegészítése WRIGHT (2000) megállapításaival. Ahol a szövetmegórző dolomitosodás azt lehetôvé tette, ott Dunham (1962) mikrofácies osztályozási rendszerébe soroltuk be a mintákat. Amennyiben ez nehézségekbe ütközött, RANDAZZO \& ZACHOS (1984) osztályozási módszerét alkalmaztuk. A különböző breccsa- és kataklázit-típusok leírásához WoOdCOcK \& MoRT (2008) osztályozási rendszerét vettük figyelembe, amely a cement ,a mátrix és a különböző méretú szemcsék alapján osztályozza a tektonikus kőzeteket (2. ábra). Az érkitöltések morfológiai alapú osztályozása Bons (2000) és PASSCHIER \& TROUw (2005) alapján történt.

A makroszkópos és normál mikroszkópi vizsgálatokat követően fluoreszcens és katódlumineszcens mikroszkópos vizsgálatokat végeztünk, hogy az esetleges rejtett szöveti bélyegeket feltárjuk. A fluoreszcens mikroszkópi vizsgálatok során UV (Olympus U-MNU-2 szúrốkocka) illetve a kék-ibolya (Olympus U-MWBV2 szúrókocka) gerjesztő hullámhosszt alkalmaztunk. A rövidebb hullámhosszúságú (360-370 nm) gerjesztés a szervesanyag-tartalmú képződmények esetében bizonyult hatékonyabbnak, míg a nagyobb hullámhosszú gerjesztésre (400-440 nm) egyes karbonátásványok mutattak intenzív fluoreszcenciát.

A petrográfiai feldolgozást, illetve a fluoreszcens mikroszkópi vizsgálatokat egy higanygőzlámpával felszerelt Olympus BX-41 típusú mikroszkóppal, a katódlumineszcens mikroszkópi vizsgálatokat pedig egy Olympus BX43 típusú mikroszkópra szerelt Reliotron típusú, hidegkatódos múszerrel végeztük, 7-7,5 keV gyorsítófeszültség mellett. 

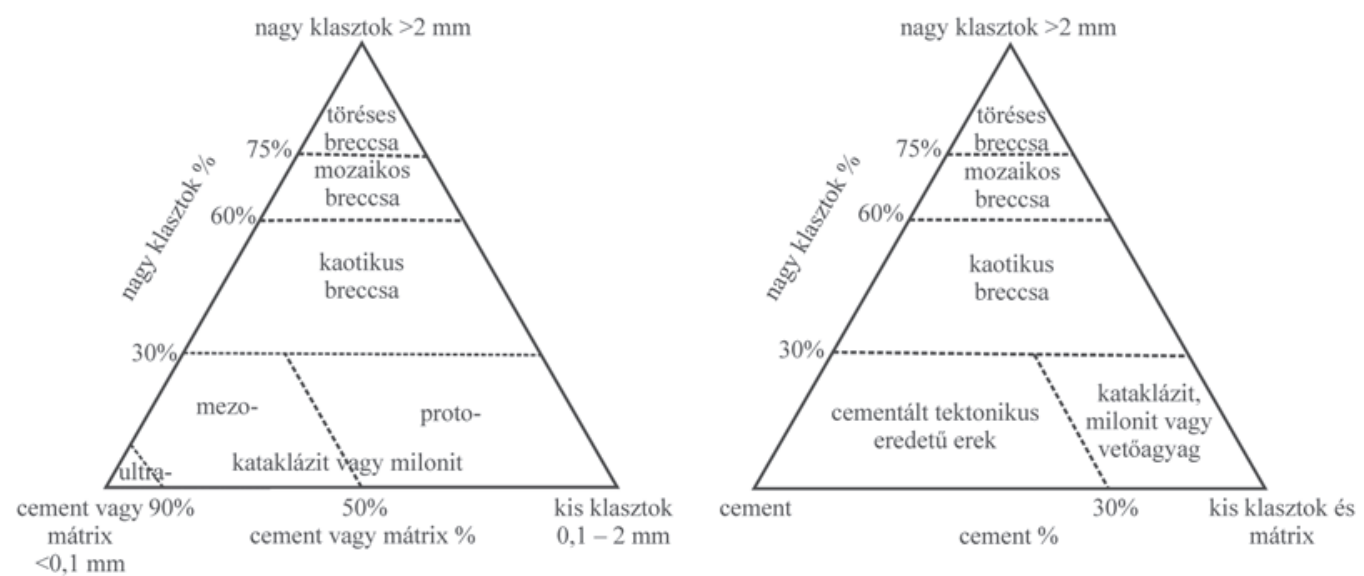

2. ábra. WoODCOCK \& MORT (2008) vetőkőzet-osztályozási rendszerének háromszögdiagramjai

Figure 2. Ternary diagrams of fault rock classification proposed by WOODCOCK \& MORT(2008)

\section{A Szegedi Dolomit Formációba sorolt kôzetek petrográfiai jellemzése}

\section{Makroszkópos megfigyelések}

A kiválasztott minták döntő többsége átkristályosodott szürke dolomit (22 db mórahalmi és üllési minta), kisebb része mészkô ( $2 \mathrm{db}$ üllési minta), néhány minta a mezozoos aljzatra települő középső-miocén abráziós konglomerátum kavicsanyagából származó dolomittörmelék (3 db üllési minta). A karbonátfestés alapján a minták majdnem mindegyike vasmentes dolomitnak bizonyult, csak néhány kalcit anyagú repedéskitöltés, illetve a mészkő festődött rózsa-, illetve mályvaszínúre.

A mórahalmi terület vizsgált kôzetei világosszürke, sötétszürke színú, változó mértékben töredezett, többnyire inhomogén mikrokristályos dolomitból állnak. A kevésbé töredezett mintákon világosszürke, szabálytalan elrendeződésű foltok, illetve világosszürke-sötétszürke, közel párhuzamos és hullámos lefutású sávok váltakozása figyelhetô meg (I. tábla, 1. kép). Általánosan jellemzó a változó mértékú töréses porozitás (I. tábla, 1 . és 2 . kép), ami a vizsgált fúrás nagyobb mélységből származó mintáiban breccsaporozitásba megy át (I. tábla, 2. kép). A fentieken túl csatornás és üreges pórusok is elkülöníthetôek (I. tábla, 3. kép). A különféle pórusokat részlegesen vagy teljesen fenn-nőtt, fehér, milliméteres méretû́ kristályok töltik ki.

Az üllési fúrásokból származó középső-triász minták mindegyikén megfigyelhetô valamilyen fokú töredezettség. A vizsgált minták többsége monomikt vagy oligomikt (a klasztok különböző színú és szövetú dolomitfajták) breccsaként sorolható be. Petrográfiai alapon töréses breccsa, mozaikos breccsa és kataklázit sávokat tartalmazó kaotikus breccsa egyaránt előfordul. Egy-két kivételtől eltekintve a sötét színú, nagyon finomkristályos alapkőzeten nem figyelhetôek meg elsődleges üledékszerkezeti jegyek, ugyanakkor már makroszkóposan több utólagos repedéskitöltó karbonátfázis különíthető el. A leggyakoribb póruskitöltő cement a fehér pátos dolomit, ami több generációs repedéseket és üregeket egyaránt kitölthet. Ezek a diszkrét törésektől a nagy mátrix- tartalmú mozaikos breccsákig egymást többszörösen felülbélyegzố viszonyban is megjelenhetnek (I. tábla, 4. kép).

A tektonikusan leginkább érintett dolomitbreccsában a mátrixot többnyire a kőzet saját őrleménye adja. A kézipéldányokon belül a klasztok méreteloszlása és a mátrix aránya alapján szabálytalan sávok rajzolódnak ki, melyekben a méret csökkenésével párhuzamosan a klasztok alakja egyre nagyobb szögszámú poligonnal (>5) közelíthető. A nagyobb mátrix-tartalmú és kisebb klasztméretú tartományok (proto) kataklázitnak minősíthetők (I. tábla, 5. és 6. kép). Egyes mintákban (I. tábla, 7. kép) a mátrix vörösbarna színú, ami vastartalmú cementfázis (pl. sziderit és/vagy vasoxid-hidroxid) jelenlétére utal, ezt erôsíti meg néhány sajátalakú piritkristály megjelenése.

Gyakori szöveti elemek a fekete szutúrás sztilolitok, melyek finomszemcsés piritkiválásokat tartalmaznak. Ezek néhol csak a breccsa klasztjain belül, míg máshol a mátrixot harántolva figyelhetők meg. Az egyetlen azonosítható makrofosszília egy akár centiméteres nagyságrendú vastag héjú kagylótípus (Megalodus?), melyet azonban csak a bizonytalan rétegtani helyzetben megjelenő sötétszürke mészkőben figyeltünk meg (I. tábla, 8. kép). Számos mintán fényes vetôkarcokat, néhol ásványlépcsőket tartalmazó vetősíkokat dokumentáltunk.

\section{A mórahalmi minták mikroszkópos jellemzése}

\section{A kőzetszövet jellemzése}

A mórahalmi előfordulásból származó dolomit, illetve dolomitbreccsa klasztjai vékonycsiszolatban megfigyelhetô szövetük alapján részben szövetmegőrző, részben szövetromboló dolomitosodásról tanúskodnak. A karbonátfestés alapján minden minta teljesen dolomitosodott, vasmentes dolomitból épül fel. Kalcit kizárólag néhány mintában érkitöltésként fordul elô.

A szövetmegôrző dolomitosodást szenvedett minták uralkodóan sztromatolitos és szemcsékből (pelletek, peloidok, onkoidok, bioklasztok, intraklasztok) felépülő mész- 
üledék dolomitosodásával létrejött dolomitból (a továbbiakban: szemcsés dolomit) állnak.

A sztromatolitos dolomitban a lemezes szerkezet egyértelmúen felismerhető (boundstone szövet), azt afanokristályos és nagyon finom kristályos dolomit váltakozása adja (3. ábra, a). A helyenként hullámos bekérgezésben (ami mikrobás szövedékre utalhat) mikritcsomók, peloidok különíthetőek el. A lemezességgel közel párhuzamosan kerek-
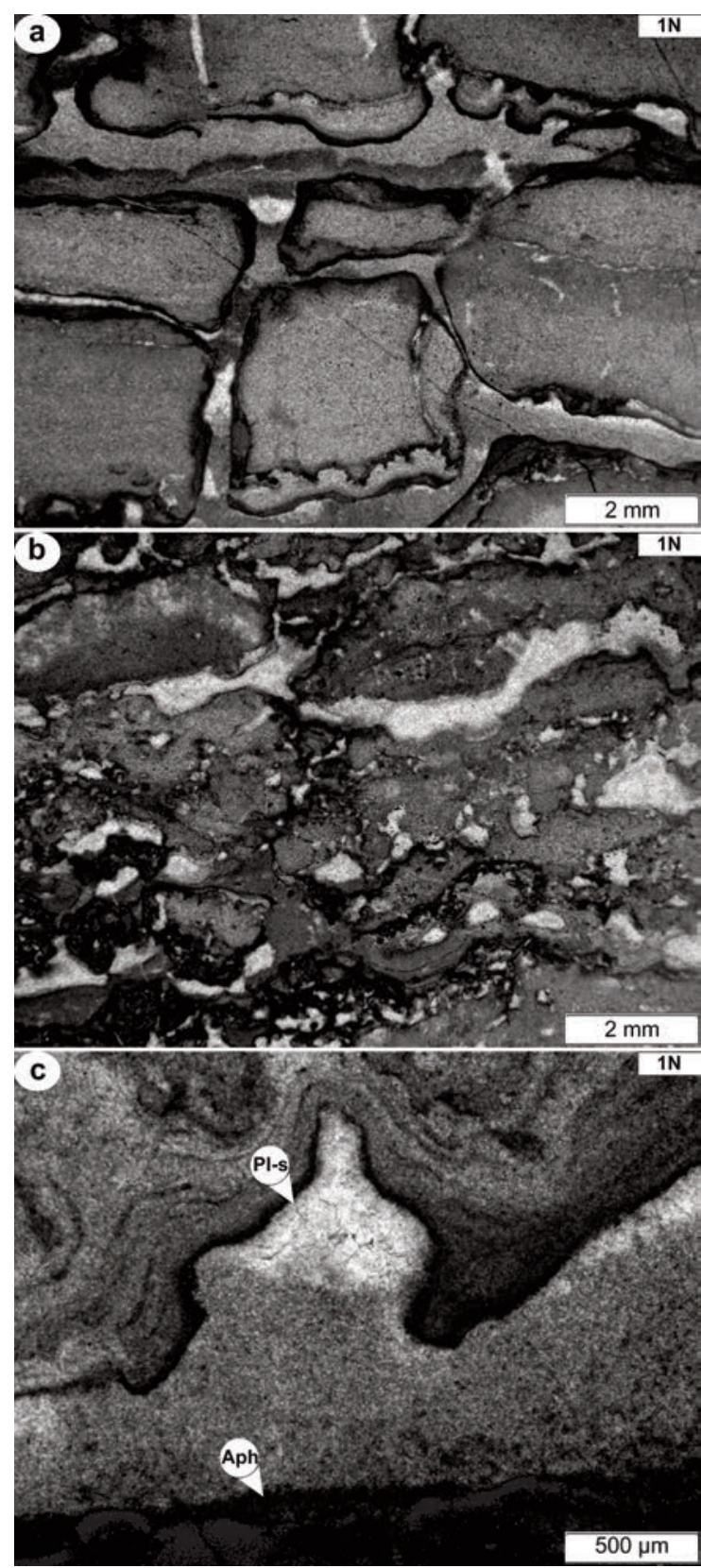

3. ábra. A mórahalmi sztromatolitos dolomit jellemző szöveti képei. a) Sztromatolitos dolomit száradási repedésekkel; b) Sztromatolitboundstone fenesztrális pórusokkal; c) Geopetális póruskitöltés afanokristályos (Aph) dolomittal és világos, zárványszegény planáris-s típusú dolomittal (Pl-s)

Figure 3. Typical textures of the stromatolitic dolomite from Mórahalom area. a) Stromatolitic dolomite with desiccation cracks; b) Stromatolitic boundstone with fenestral pores; c) Geopetal structure in a pore filled by aphanotocrystalline dolomite (Aph) and planar subhedral dolomite (Pl-s) crystalls ded vagy lencseszerú fenesztrális, illetve lemezrepedéssel létrejött szabálytalan alakú pórusok figyelhetők meg (3. ábra, b). Ezek eredeti, geopetális kitöltése szintén megőrződött, így megállapíthatóak a leülepedéskori függőleges és vízszintes irányok. A pórusok alsó részén afanokristályos, feljebb nagyon finomkristályos, barnás árnyalatú, zárványgazdag kitöltés észlelhető, majd a pórusok felső részén finom-középkristályos (50-200 ㅆm-es), zárványszegény, planáris-s (szubhedrális) típusú dolomit szúkíti le a pórusteret drúzás jelleggel (3. ábra, c). A nagyobb méretú pórusokban ez a planáris-s típusú dolomit gyakran fokozatos átmenetet mutat durvakristályos, nem-planáris-a (anhedrális) dolomitba.

A szemcsés dolomitban az uralkodó szemcsetípus az intraklaszt, a peloid és a bekérgezett szemcse, továbbá kisebb arányban bioklaszttöredék jelenik meg. Az intraklasztok ritkán érintkeznek, méretük néhány millimétertől centiméteres nagyságrendig terjed, felületükön helyenként mikritbevonat figyelhetô meg (4. ábra, a). Az intraklasztok belső felépítése változatos: helyenként azonosíthatók az elsődleges szöveti elemek (pl. lemezes szerkezet, bekérgezett szemcsék [4. ábra, b]), de jellemzően átkristályosodott, finomközépkristályos planáris-s típusú dolomitból állnak. Néhány intraklasztban 100-300 $\mu$ m-es kristályméretû planáris-p (porfirotópos) vagy planáris-e dolomitot azonosítottunk, melynek kristálylapjai helyenként ívelt jellegúek (4. ábra, c és d). A bekérgezett szemcsék között egyértelmúen azonosíthatók az onkoidok, melyek mérete néhány milliméterestől centiméteresig terjed (4. ábra, e). Számos esetben azonban az afanokristályos szegélytől eltekintve a bekérgezett szemcse belsô része teljesen átkristályosodott, azt finom-középkristályos planáris-s típusú dolomit alkotja. A bioklasztok között gyakori a crinoidea, a kagyló - esetleg brachiopoda héjtöredéke (4. ábra, f), valamint a mészalgamaradvány. A szemcsék közötti teret nagyon finomkristályos, barnás árnyalatú dolomit, illetve finom-középkristályos planáris-s típusú dolomit tölti ki, melyek között éles, szabálytalan lefutású a határvonal. A planáris-s típusú dolomit a nagyobb pórusok, repedések felé fokozatosan nagyon durvakristályos nyeregdolomitba megy át (4. ábra, a).

A mórahalmi mintákra általánosan jellemző a szövetromboló dolomitosodás. Ezeket a kőzeteket planáris-s típusú, polimodális kristályméreteloszlású, mozaikos szövetú dolomit építi fel, amely nem tartalmaz relikt szöveti elemeket. Szövetükben szabálytalan alakú, általában diffúz határú, nagyon finomkristályos tartományok váltakoznak zárványgazdag, finomkristályos planáris-s dolomitból álló területekkel (5. ábra, a).

\section{A deformációs bélyegek jellemzése}

A dolomitosodott kőzeteket legalább három fázisban töréses deformáció érte. A legnagyobb pórusokat, így a breccsásodott képződmények repedésrendszerének döntő részét zónás, enyhén unduláló kioltású nyeregdolomit tölti ki, ami hasonló habitusú az alapkôzet üregeit kitöltố nyeregdolomithoz (5. ábra, b és c). A kristályok zónásságát zárványokban gazdagabb és zárványokban szegényebb növe- 
kedési zónák egymásra következése adja. Ez a dolomitcement a kitöltetlen pórusok falán fenn-nőtt formában jelenik meg, kitöltött üregekben drúzás, illetve szintaxiális jellegú. Az utóbbi esetben a kristályok a repedés fala felől annak belseje felé növekedtek. Ez az érkitöltő nyeregdolomit petrográfiai jellege alapján rokonságot mutat az intra- klasztos mellékkőzetben helyettesítő fázisként megjelenő porfirotópos dolomittal (4. ábra, c és d).

A nyeregdolomit által cementált repedésrendszert legalább két további törésgeneráció harántolja, melyek közül az elsôt általában finomkristályos ( 20-50 $\mu \mathrm{m})$, víztiszta dolomit, a másodikat pedig finom-közepes kristályméretú
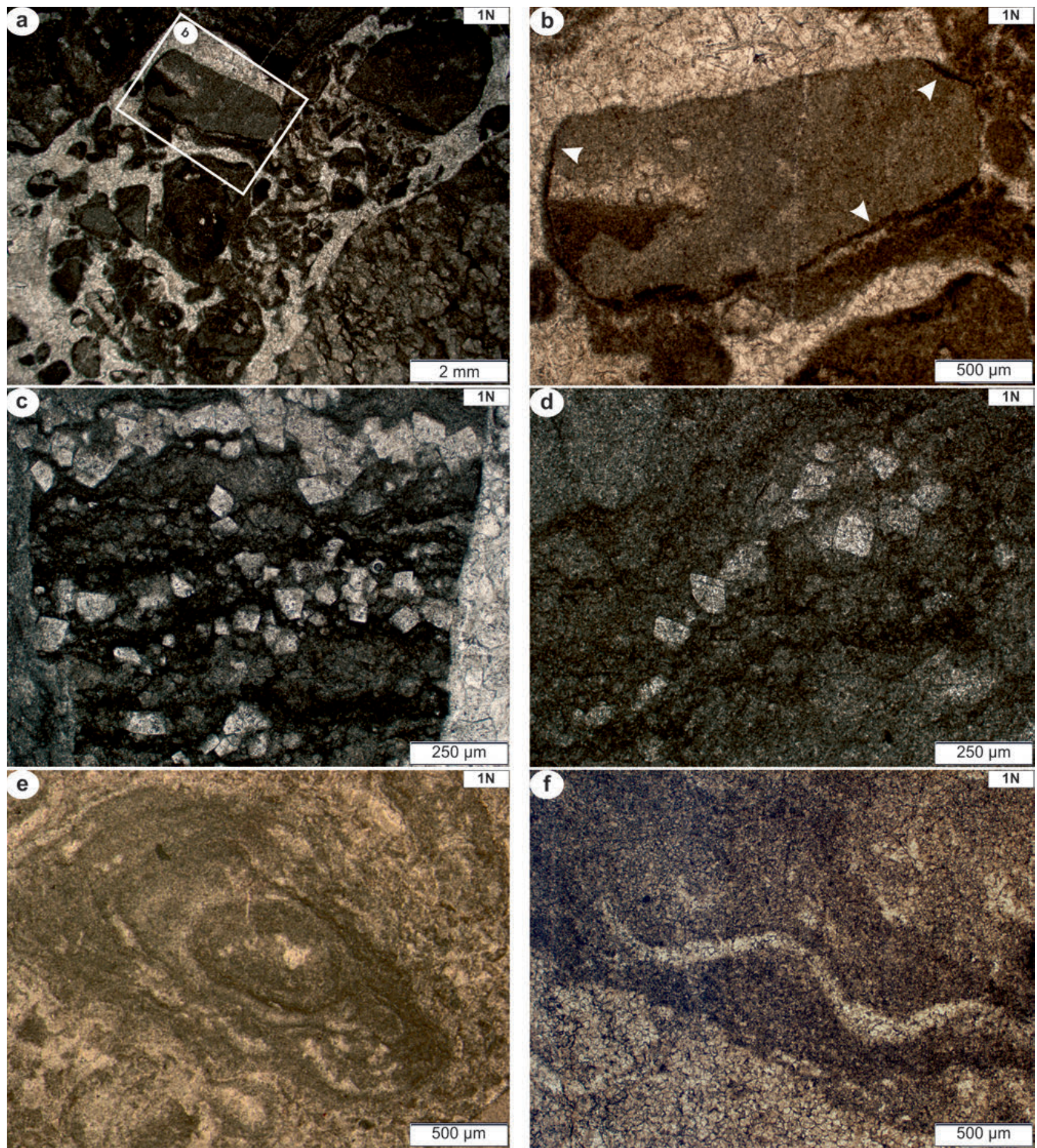

4. ábra. Szemcsés, szövetmegőrző dolomit szöveti képe a mórahalmi mintaterületről. a) Intraklasztos dolomit mikrites és pátos cementanyaggal; b) Intraklaszt mikritbevonattal (nyilak); c) Porfirotópos-euhedrális dolomitkristályok lemezes belső szerkezetủ intraklasztban; d) Középkristályos porfirotópos dolomit nagyon finomkristályos dolomitban; e) Onkoid; f) Onkoid magvaként szolgáló átkristályosodott kagylóhéj

Figure 4. Thin section photomicrographs of fabric retentive dolomite sample composed of crystals and grains from Mórahalom area. a) Intraclastic dolostone cemented by sparry and micritic dolomite; b) Intraclast with micritic dolomite rim (arrows); c) Porphyrotopic to euhedral dolomite crystals within a laminated intraclast; $d$ ) Medium crystalline porphyrotopic dolomite within very finely crystalline dolomite; e) Oncoid; f) Bivalve shell nucleus within an oncoid 
( 10-100 $\mu \mathrm{m})$ dolomit mellett opak fázisok (pirit, illetve szerves anyag, valószínúleg szilárd bitumen) töltik ki.
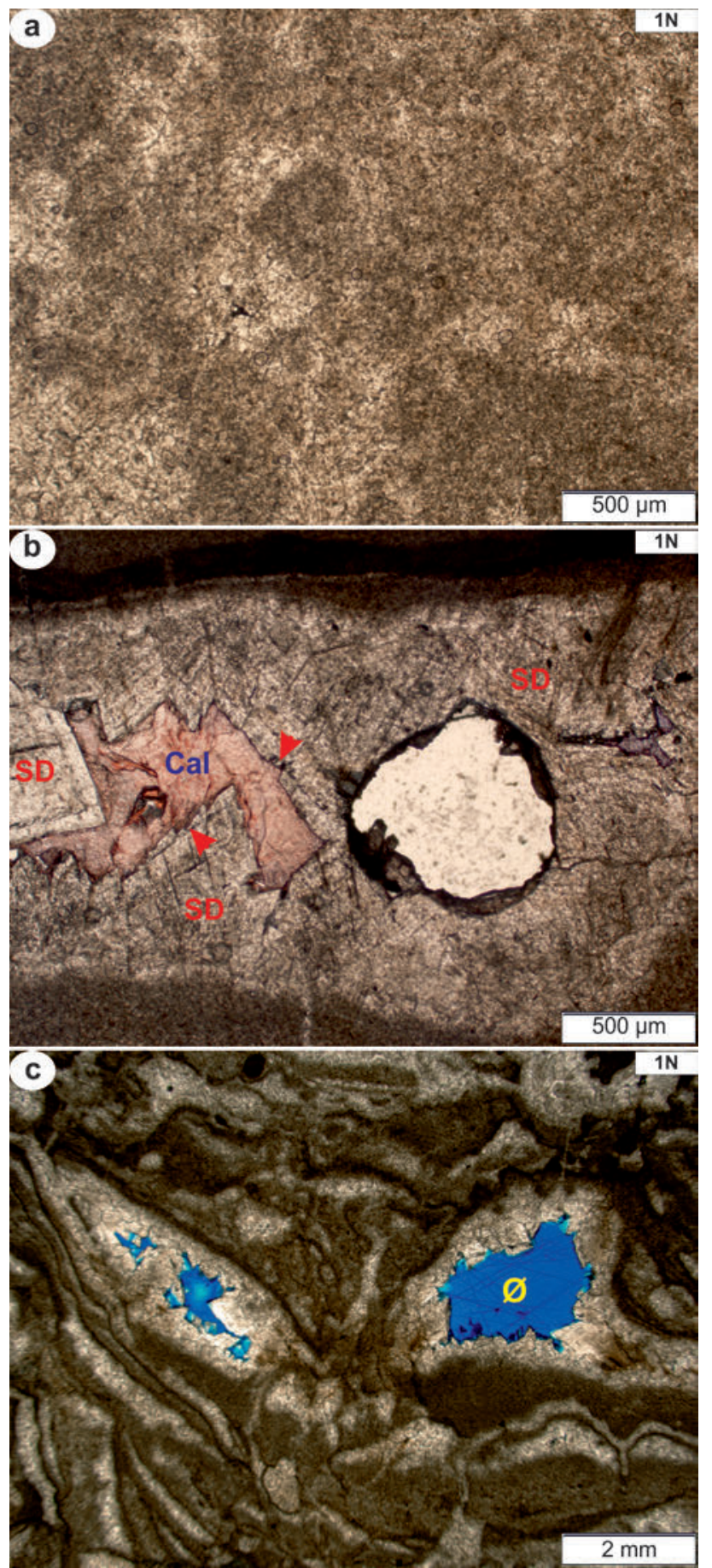

5. ábra. Szövetromboló dolomit és póruskitöltő karbonátok a mórahalm mintákban. a) Planáris-s típusú, polimodális kristályméreteloszlású, felhős, mozaikos szövetü, nagyon finomkristályos-finomkristályos dolomit; b) Nyeregdolomit cementet (SD) követő vasas kalcit (Cal), a dolomiton oldási nyomokkal (piros nyilak); c) Kék mủgyantával kitöltött oldásos üregek (Ø) sztromatolitos dolomitban, az üregek falát nyeregdolomit vonja be

Figure 5. Thin section photomicrographs of fabric-destructive dolomite and pore filling carbonates in samples from Mórahalom. a) Planar-s type finely to very finely dolomite characterized by polimodal crystal size distribution and fogged mosaic texture; b) Saddle dolomite (SD) with dissolved crystal faces (red arrows) and subsequent ferrous calcite (Cal) cement; c) Stromatolitic dolomite with blue epoxy filled open pore space (Ø) and pore-lining saddle dolomite cement
Némely nagyméretû, másodlagos üreges pórus belsejében — utolsó cementáló fázisként — zárványszegény kalcit, illetve vasas dolomit, helyenként sziderit figyelhető meg. A kalcit és a dolomit határfelületénél a nyeregdolomit visszaoldódására utaló beöblösödések jelentkeznek (5. ábra, $b$ ). A nyeregdolomit kiválását követően számos üreg kitöltetlen maradt, így a kőzetek makroporozitása jelentős (5. ábra, c).

\section{Az üllési minták mikroszkópos jellemzése}

\section{A kőzetszövet jellemzése}

Az üllési területrôl származó középső-triász kőzetekben a prekurzor üledék eredeti szövetének besorolását megnehezíti azok nagyfokú töredezettsége és átkristályosodottsága. Mikroszkópos megfigyelés alapján több olyan minta erôsen tektonizáltnak bizonyult, ami makroszkóposan nem látszott deformáltnak. A breccsát alkotó dolomitklasztok mikroszövete gyakran teljesen megegyezô, de előfordulnak különböző szövetú klasztokat tartalmazó, azaz polimikt dolomitbreccsák. A vizsgált mintákban a mátrix/klaszt arány nagyfokú változatosságot mutathat. A dolomitok szöveti, valamint a karbonátok mikrofácies osztályozási rendszereit kombinálva a szövetmegőrző, illetve a szövetromboló dolomitosodást szenvedett mintákat két-két csoportba soroltuk, továbbá elkülönítettünk egy részben szövetmegőrző, átmeneti típust.

Egy minta esetében a dolomitos rétegsorban repedezett, részlegesen dolomitosodott mészkő fordult elô. A mészkôminta mikrofáciese peloidos, bioklasztos grainstone-packstone, mely hintetten planáris-p dolomitkristályokat és halmazokat tartalmaz (6. ábra, a). A szemcsék túlnyomóan rosszul osztályozott peloidok, továbbá juvenilis kagylóhéjtöredékek, ostracoda- és foraminiferavázak (6. ábra, b), alárendelten egy-egy gastropoda- és mészalgatöredék is felismerhetô. A foraminifera együttest felsô-anisusi-ladini primitív agglutinált Glomospira-félék alkotják (SzUROMINÉ KoRECz A. szóbeli közlés, 2016). Ez a minta tartalmazza a makroszkópos leírásnál említett vastag héjú kagyló (Megalodus?) maradványát. Az alapanyagban a mikrites-mikropátos és a pátos kalcit szabálytalanul oszlik el (6. ábra, b).

A szövetmegőrző dolomitosodást szenvedett vasmentes dolomit fő szemcsetípusai a peloidok és a bioklasztok, de ritkábban intraklasztok is megfigyelhetôk. Számos esetben az afanokristályos szegélytől eltekintve a szemcsék belső része teljesen átkristályosodott, az finom-középkristályos planáris-s típusú dolomitból áll. Helyenként a peloidokon rostos-tûs cement reliktuma figyelhető meg (6. ábra, c). A szemcsék közötti térben afanokristályos - nagyon finomkristályos és finom-középkristályos planáris-s típusú dolomit szabálytalanul oszlik el (6. ábra, d).

Szövetmegőrző dolomitosodást szenvedhettek azok az átmeneti jellegú minták is, melyek uralkodóan afanokristályos - nagyon finomkristályos dolomitból állnak (7. ábra, a). Ezek egyes mintákban teljesen homogének, alárendelten finomlemezes szerkezet, míg néhol intraklasztok ismerhetők fel bennük. 

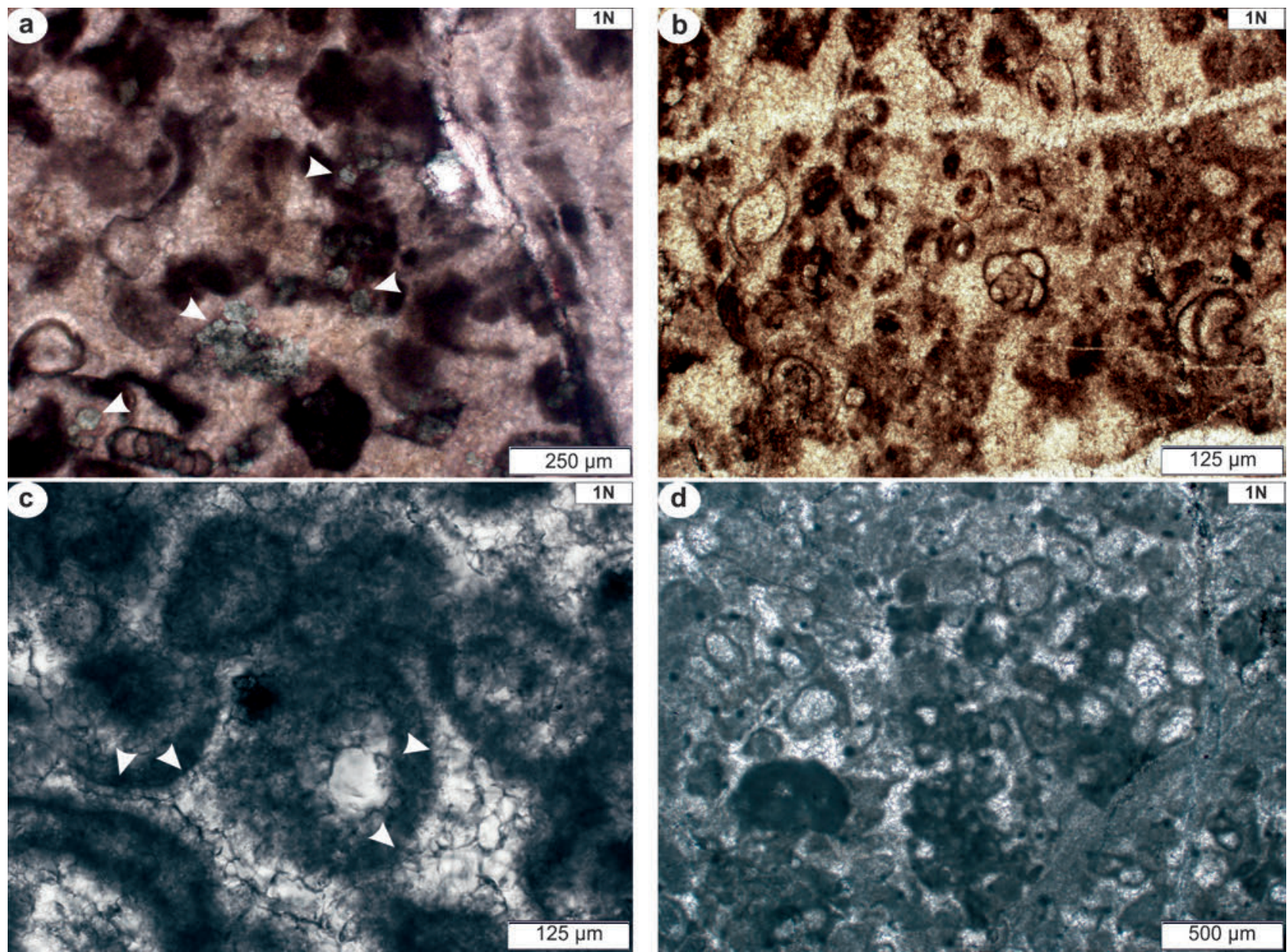

6. ábra. Mészkő és szövetmegőrző dolomit szöveti képe üllési mintákon. a) Grainstone szövetű mészkő hintett, euhedrális dolomitkristályokkal (nyilak); b) Grainstone szövetủ mészkő kagylóhéjtöedékekkel, foraminiferákkal és mikritesedett bioklasztokkal; c) Visszaoldódott magvú peloid sugaras, szálas cementtel (nyilak); d) Megőrződött szövetű peloidos dolomit

Figure 6. Thin section photomicrographs of limestone and fabric-retentive dolomite from Üllés area. a) Limestone with grainstone fabric and euhedral dolomite crystals (arrows); b) Limestone with grainstone fabric containing mollusc shells, foraminifers and micritized bioclasts; c) Peloid with dissolved core and remnants of fibrous radial cement coating (arrows); d) Dolomite characterized by preserved peloidal fabric

Az üllési területről származó kőzetekben a leggyakoribb azonosítható szövettípus a planáris-s típusú, finom-középkristályos, zárványgazdag (barnás mikroszkópi árnyalatú) dolomit. Ennek kristályméret-eloszlása többnyire unimodális, de helyenként polimodális, változó kristályméretű területek is előfordulhatnak bennük. Néhol felsejlik egy-egy kerekded, vagy megnyúlt, egykori szemcsére emlékeztető alakzat, de többnyire a dolomitosodás teljesen szövetrombolónak tekinthetô (7. ábra, b).

Néhány mintában megfigyelhetô, hogy a fenti szövettípusok közép-durvakristályos euhedrális dolomitot tartalmaznak. Ezek részarányának növekedésével a kőzetszövet fokozatosan megy át planáris-s és nem planáris-a dolomit közötti átmeneti típusba. Ebben már semmilyen relikt szöveti elemet nem lehet felfedezni. A dolomitkristályok magva gyakran különféle szilárd és fluidumzárványokban gazdag, és általában egy tiszta továbbnövekedési szegély veszi körül. A kristályok helyenként unduláló kioltást mutatnak, és a kristálylapok között gyakori az opak fázis (7. ábra, c). A továbbiakban a könnyebb áttekinthetôség érdekében cukor- szövetű (sucrosic) dolomitként hivatkozunk erre az átmeneti dolomittípusra.

\section{A deformációs bélyegek jellemzése}

A dolomitosodást követően több fázisban töréses deformáció érte a kőzeteket. Az így létrejött másodlagos pórusokat különböző anyagú karbonátok (dolomit, kalcit, sziderit) cementálják. Egyes mintákban akár nyolc-tíz különféle repedéskitöltő generáció különíthető el, melyek többsége azonban csak egy-egy esetben volt megfigyelhetô, így feltehetôen lokális jelentôségú. Mindezeket figyelembe véve a következőkben csak azokat a repedéskitöltő típusokat mutatjuk be részletesen, melyek általánosan elterjedtek az üllési mintaterületen. A repedéskitöltések egymáshoz viszonyított korát azok átmetszési viszonyai alapján határoztuk meg.

Megfigyelésünk szerint az első generációt azok a diffúz határú repedéskitöltések képviselik, melyek a kőzet alapszövetével együtt átkristályosodtak. Ezeket csak az alapkőzetnél jóval világosabb mikroszkópi árnyalatuk és zár- 
ványokban szegényebb kristályaik teszik felismerhetôvé (II. tábla, l. kép).

Számos magszakaszban megfigyelhetőek olyan brecscsák, melyeket mikrokristályos dolomit, helyenként agyag-
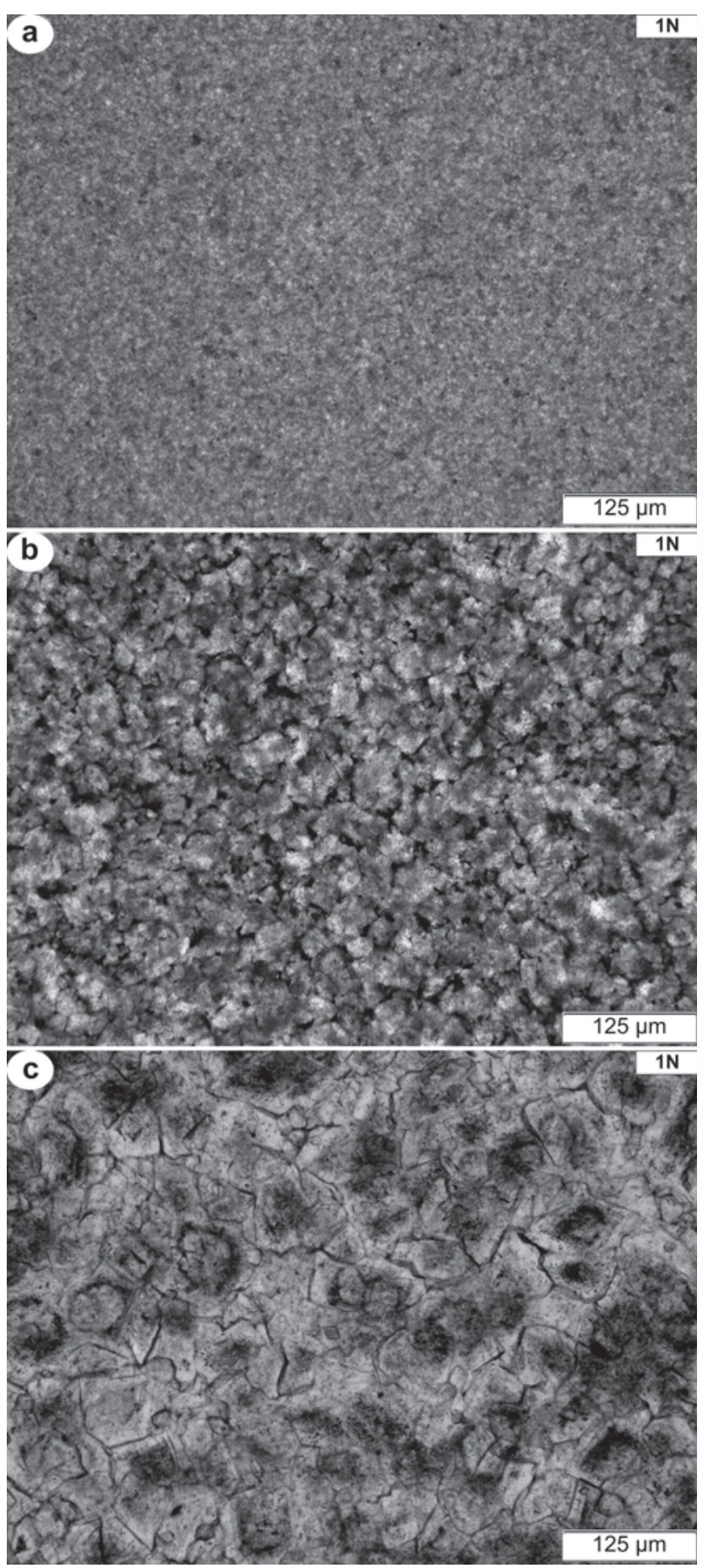

7. ábra. Szövetromboló dolomitosodáson átment dolomitok jellegzetes szövet képei az üllési mintákban. a) Afanokristályos - nagyon finomkristályos dolomit; b) Planáris-s típusú, finom-középkristályos dolomit; c) „Cukorszövetü” dolomit planáris-s és nem planáris-a közötti átmeneti típusú dolomitszövettel, zárványgazdag, felhős magvú kristályokkal

Figure 7. Fabric-destructive dolomite textures in samples from Üllés area. a) Aphanocrystalline - very finely crystalline dolomite; b) Finely to medium crystalline planar-s type dolomite; c) Sucrosic dolomite with transitional texture (planar-s to nonplanar-a) and incusion rich cloudy cores ásványok cementálnak. A breccsaklaszt és a mátrix $(<0,1$ $\mathrm{mm}$ ) anyaga a dolomitosodott kôzet saját ốrleménye, ami bizonyos sávokban kataklázitnak tekinthetô (II. tábla, 2. kép, I. tábla, 5. és 6. kép). A nagyobb klasztokban többnyire csak néhány korábbi repedéskitöltő fázis, illetve sztilolit figyelhető meg. Ezt a breccsásodási eseményt a nyeregdolomithoz viszonyított helyzete alapján legalább két csoportba sorolhatjuk. Az egyiknél a breccsás szövetet harántoló repedésekben és üregekben cementként jelenik meg a nyeregdolomit, míg a másik — ritkábban előforduló — típusnál klasztként.

Az üllési mintákban általánosan elterjedt a fehér, durvakristályos, akár néhány milliméteres kristályméretú, üregés repedéskitöltő nyeregdolomit. A nyeregdolomit kristályai leggyakrabban szabálytalan alakú — feltehetően oldódásos eredetû - üregek falára nôttek. A nyeregdolomit kristályosodását követôen fennmaradt pórusok gyakran megőrződtek, de helyenként késóbbi cementfázisként változatos ásványegyüttes (pl. kalcit, sziderit, kvarc, agyagásványok) csökkenti a porozitást. A nyeregdolomit kristályainak kioltása unduláló, alakjuk metszettól függően a romboéderestől (II. tábla, 3. kép) a torzult, görbült lapú „barokk”jellegú kristályokig terjedhet (II. tábla, 4. kép). A legtöbb esetben növekedési zónásságot mutatnak, amit zárványokban gazdag, illetve zárványszegény zónák váltakozása definiál. A növekedési zónákban, illetve a kristályok felhős magjában szilárd- és fluidumzárványok egyaránt előfordulnak. Megjegyzendő, hogy a nyeregdolomit repedéskitöltést a középsô-miocén abráziós konglomerátumból mintázott sötétszürke dolomitkavicsokon belül is megfigyeltük.

A nyeregdolomit generációt átmetsző repedésekben egy fehér, víztiszta, mikropátos-pátos dolomittípust különítettünk el. Ez fluidumzárványokat csak igen ritkán tartalmaz, leginkább másodlagos zárványegyüttesek formájában. Szöveti jellemzói alapján ez a típus jól korrelálható a mórahalmi mintákban leírt fiatal, víztiszta, pátos dolomiterekkel (II. tábla, 5. kép).

Az üllési minták egyik jellegzetes cementfázisa a téglavörös színú, mikrokristályos, szideritcement. Ez a cementtípus agyagásványokkal együtt a nyeregdolomittal részlegesen kitöltött erek belső részén, illetve vetôbreccsák cementanyagaként is megjelenik, (I. tábla, 4. és 7. kép).

A mórahalmihoz hasonlóan az üllési területen is megjelenik, továbbá felülbélyegez szinte minden más képződményt az a repedésgeneráció, mely mikropátos-pátos dolomitot, piritkristályokat és opak szerves anyagot tartalmaz (II. tábla, 6. kép). Ez az ásványegyüttes hajszálrepedésektől a breccsás mátrixig sokféle szöveti helyzetben előfordul, és szinte minden vizsgált mintában megfigyelhetô volt.

A kőzetekben számos nyomásoldódási bélyeget megfigyeltünk a mikrosztilolit kötegektól a jól fejlett, centiméteres amplitúdójú varratvonalszerú, fürészfogas lefutású sztilolitokig. A legtöbb előfordulásukhoz opak szerves anyag, illetve pirit dúsulása kapcsolódik. A többi képződményhez való viszonyuk alapján legalább két csoportra bonthatóak. Az első csoport sztilolitjait a legtöbb repedéskitöltő fázis harántolja, gyakran jelennek meg breccsák 
klasztjain belül (II. tábla, 7. kép). A másik csoportot azok a sztilolitok alkotják, melyek a legtöbb repedéskitöltő fázist felülírják, gyakran breccsaklasztok között is megjelennek (II. tábla, 8. kép). Ezek helyzete csak a legutolsó piritesbitumenes repedéskitöltéshez viszonyítva bizonytalan, de általában felülbélyegzik azokat is.

\section{Lumineszcens mikroszkópián alapuló vizsgálatok}

A karbonátásványok katódlumineszcens, illetve fluoreszcens mikroszkópos vizsgálata segítségével kimutathatók rejtett — normál megvilágítással nem látható — mikroszerkezeti elemek. A továbbiakban csak a mindkét vizsgált területen megjelenő, ezáltal egymással feltehetôen korrelálható szöveti elemek jellegzetes lumineszcens tulajdonságait mutatjuk be.

\section{Fluoreszcens mikroszkópi megfigyelések}

Az UV és kék-ibolya fényú besugárzás hatására fluoreszcens jelenséget mutatott az a legfiatalabb repedéskitöltő dolomit, amely a kristálylapok között szilárd bitument és piritet tartalmaz (III. tábla, 1. kép). A fluoreszcens jelenséget minden esetben a karbonátkristályok mutatták, a szerves anyag maradványok nem fluoreszkáltak. Ehhez a típushoz kapcsolódóan néhány mintában olyan breccsás szövet vált láthatóvá, ami normál mikroszkóp alatt nem, vagy csak nagyon bizonytalanul volt dokumentálható (III. tábla, 2. kép). Hasonló kifejlődésû pirithintéses, fluoreszkáló karbonátos cementfázist figyeltünk meg a vizsgált középsô-miocén breccsák homokköves mátrixának cementanyagaként.

Kék-ibolya fény hatására zölden fluoreszkáltak azok a pátos dolomitkristályok, melyek fenesztrális pórusokat, illetve visszaoldódott magvú peloidokat töltenek ki drúzás jelleggel (III. tábla, 3. kép).

Az UV-fluoreszcens vizsgálatok során a nyeregdolomitokhoz kapcsolódóan mindkét előfordulási területen dokumentáltuk kőolajzárványok jelenlétét. Az olajzárványok többnyire - a nyeregdolomit növekedési zónáiban megfigyelt - elsődleges zárványegyüttesekben jelennek meg (III. tábla, 4. kép), de másodlagos zárványegyüttesekben szintén előfordulnak.

\section{Katódlumineszcens mikroszkópi megfigyelések}

A nyeregdolomit növekedési zónáihoz kapcsolódóan figyeltük meg a legmarkánsabb katódlumineszcens jelenséget. A különböző kőzetmintákból származó nyeregdolomit minták katódlumineszcens képe egymáshoz nagyon hasonló. Ezekben általában keskeny (néhányszor 10 um-es), nem lumineszkáló, és fényes, narancssárga lumineszcenciájú, illetve tompa lumineszcenciával jellemezhetô növekedési zónák váltakoznak (IV. tábla, 1. kép). A nyeregdolomitok kiválását követően szabadon maradt pórusokat helyenként kitöltő agyagásványok egy része tompa, ibolyaszínú lumineszcenciát mutatott, ami alapján a kaolinit csoport tagjaként határozhatók meg.
Néhány víztiszta pátos dolomitérben az elsődleges, nem lumineszkáló kristályok kiválása után visszamaradt pórustérben a kristálylapok alakját megőrző, utólagos cementációra utaló alakzatok váltak láthatóvá (IV. tábla, 2. kép).

Halvány narancsvörös színnel lumineszkál a bitumenes, pirites dolomiterek néhány mikropátos kristálya. Ezekben a mintákban a fluoreszcenciához hasonlóan a katódlumineszcens mikroszkóp alatt is kirajzolódik a rejtett breccsás szövet (IV. tábla, 3. kép). Azonban itt jellemzően a mátrixanyag olyan kristályai mutattak lumineszcenciát, amelyek kék-ibolya fény hatására nem gerjesztődtek.

A repedéskitöltő típusokon kívül a bekérgezett szemcsék és a mikrobiális szövedék mikrites anyaga mutatott nagyon halvány lumineszcenciát (IV. tábla, 4. kép). A kékibolya fluoreszcens és a katódlumineszcens módszereket kombinálva az tapasztalható, hogy amelyik ásványfázis az egyik gerjesztési módszer hatására lumineszkál, az a másik típusú sugárzás hatására inaktív marad (III. tábla, 3. kép és IV. tábla, 4. kép).

\section{Az eredmények értelmezése}

A Szegedi Dolomit Formáció kőzetanyagának részletes petrográfiai vizsgálata alapján felállítható a képződmény diagenezistörténeti vázlata, illetve jellemezhetők töréses deformációjának legfontosabb állomásai. A betemetődéstörténet folyamán fennálló diagenetikus környezetek elkülönítése MACHEL (1999) által javasolt rendszer alapján történt. Ennek megfelelően megkülönböztettünk felszín közeli, sekély, közepes és mély betemetődési zónákat. Az értelmezés eredményeként felállított paragenetikai sorrendet a 8. ábrán mutatjuk be.

\section{Üledékképzôdés, felszínközeli és sekély betemetôdéses folyamatok}

A mórahalmi területen a szövetmegôrzô dolomitosodást szenvedett minták — a sztromatolitos és a felismerhető szemcséket (pelletek, peloidok, onkoidok, bioklasztok, intraklasztok) tartalmazó dolomit — elsődleges bélyegei alátámasztják a korábbi vizsgálati eredmények alapján HoRvÁTH A. (1990) által feltételezett sekélytengeri-partközeli árapályöv, lagúna és homokzátony üledékképződési környezeteket. Munkájában a sztromatolitos dolomitot a peloid-alga bindstone csoportba sorolta, míg az általunk bemutatott szemcsés dolomitváltozatok HoRvÁTH A. (1990) bioklaszt-intraklaszt-peloid packstone és peloid grainstone mikrofácies-besorolásának feleltethetốk meg. Az intenzív breccsásodás és a szövetromboló dolomitosodás ellenére az üllési területen is lehetőségünk nyílt az üledékképződés jellegének felvázolására. A részlegesen dolomitosodott mészkőminta mikrofáciese peloidos, bioklasztos grainstone-packstone (6. ábra, a). A bioklasztszemcsék (Megalodus-maradvány, juvenilis kagylóhéjtöredékek, gastropoda- és mészalgatöredék, primitív agglutinált Glomospirafélékből álló foraminifera-együttes) sekélytengeri lagúna fáciest jeleznek (SzUROMINÉ KORECZ A. szóbeli közlés, 2016). 


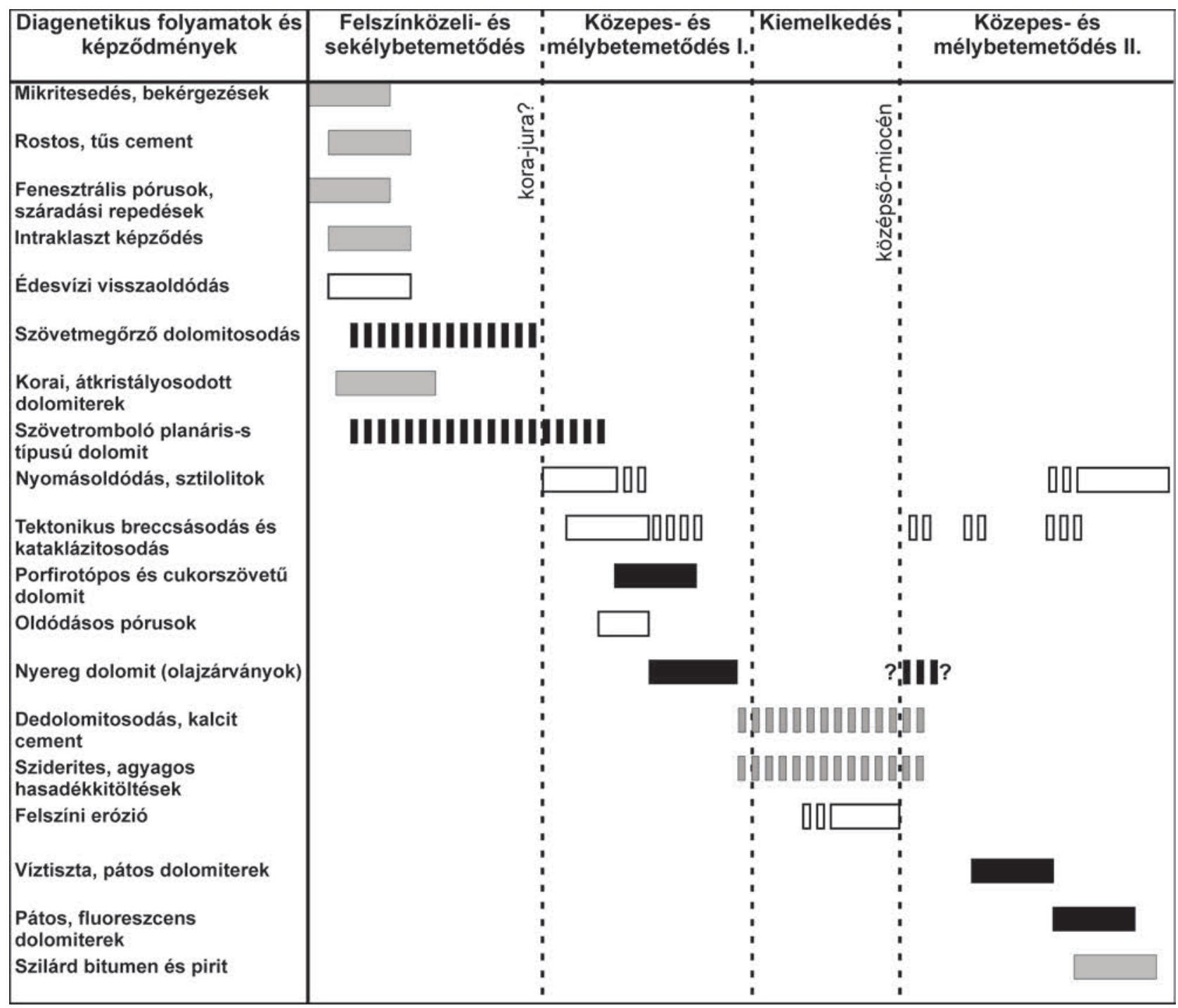

8. ábra. A Szegedi Dolomit Formáció képződményeinek paragenetikai sorrendje. A fekete téglalapok különféle dolomitokat jelölnek, az üres téglalapok jelölik a töréses és oldódásos eseményeket, a szürke négyszögek pedig az egyéb diagenetikus képződményeket vagy folyamatokat

Figure 8. Paragenetic sequence of the Szeged Dolomite Formation. Black rectangles represent different types of dolomites; open rectangles indicate different dissolution and fracturing events; grey rectangles represent other diagenetic events and phases

A munkánkban bemutatott szöveti elemek közül peritidális környezetre utalnak a száradási repedéseket és fenesztrális pórusokat tartalmazó sztromatolitok. Feltehetôen tengeri diagenetikus folyamatok eredményeként jött létre a bekérgezett szemcsék mikritburka, a szemcsék közötti mikrites cement és a szemcsék körül radiálisan megjelenố rostos-tûs cement. A fenesztrális pórusokban megfigyelt, gravitációsan rétegzett geopetális póruskitöltések alapján a leülepedett képződmények időszakosan a vadózus zónába kerültek (HAAS 1998, FlÜGEL 2004). Meteorikus hatást jelezhetnek továbbá a visszaoldott magvú bioklasztok és peloidok (FLÜGEL 2004), ezek kialakulása a tengeri üledékek időszakos szárazra kerülésével magyarázható, amelyet követően a dolomitosodás a burok szellemképét ôrizte meg. A fent leírt képződmények kialakulása valószínúleg egymással párhuzamosan (8. ábra), illetve váltakozva zajlott a felhalmozódási terület különböző részein.

A mikrobás boundstone (sztromatolit) és a felismerhető szemcséket tartalmazó kőzetekben a korai, felszínközeli dolomitosodás magyarázhatja azt, hogy a későbbi dolomitosodási események során ezek megốrizték eredeti szövetüket. Az afanokristályos - nagyon finomkristályos dolomitváltozatok, melyek szinte teljesen homogének (néhol felismerhető finomlemezes szerkezet) feltehetően szintén szövetmegőrző dolomitosodáson mentek keresztül, és az elsődleges üledékszövet mudstone vagy finomlemezes mudstone lehetett. Véleményünk szerint ez az afanokristályos - nagyon finomkristályos dolomit feleltethetô meg a HoRVÁtH A. (1990) által elkülönített, a sekély eltemetődés zónájában kialakult első dolomittípusnak, az „unimodális, aprószemcsés $(0,01 \mathrm{~mm})$, nem planáris szövetú dolomit"nak. Az eredeti szövet megőrződése felszínközeli dolomitosodással létrejött, nagyon finomkristályos dolomitokra jellemző különösen akkor, ha az eredeti üledék uralkodóan Mg-kalcit összetételú volt (HAAS 1998, MACHEL 2004).

A mindkét vizsgált területre általánosan jellemzố fi- 
nom-középkristályos planáris-s típusú dolomit korai diagenetikus eredetére utalhat, hogy olyan mikrittel bekérgezett intraklasztokban is megfigyeltük ezt a szövetromboló dolomittípust, melyek környezetében levő többi szemcse megőrizte elsődleges szövetét (4. ábra, $a$ és $b$ ). Értelmezésünk szerint ez úgy jöhetett létre, hogy az üledékgyújtốben a már szövetromboló dolomitosodáson átesett intra/litoklasztok és a belső szövetüket megôrző (kalcit vagy dolomit anyagú) intra/litoklasztok keveredtek, ezt követően pedig mikritburok vált ki a szemcsék körül. Ez a korai dolomittípus reflux dolomitosodással, vagy tengervíz cirkuláció útján is létrejöhetett a felszín közelében (WARREN 2000, MACHEL 2004), de a kialakító folyamat jellegének pontosítása további vizsgálatokat igényel. A finom-középkristályos planáris-s típusú dolomittípuson belül megfigyelt unimodális kistályméret eloszlás egyfázisú dolomitosodásra utal (SIBLEY \& GREGG 1987). Az ilyen szövet egyrészt az egykori mészüledék homogén jellegét jelezheti, vagy olyan szövetromboló dolomitosodást tükröz, mely során az üledék eredeti szövete teljesen felülíródott (RANDAZZO \& ZACHOS 1984). A vizsgált mintákban gyakori polimodális kristályméreteloszlású dolomit képződését az eredeti üledék heterogén szövete eredményezheti, vagy a több nukleációs fázissal járó, többfázisú dolomitosodás hozhatja létre (SIBLEY \& GREGG 1987). Mivel a vizsgált minták fő tömegét ez a dolomittípus alkotja feltételezhető, hogy az ezt létrehozó dolomitosodási folyamat volt a legmeghatározóbb a Szegedi Dolomit Formáció litológiai bélyegeinek szempontjából. HoRvÁtH A. (1990) azonban nem különítette el önálló csoportként ezt a dolomitváltozatot, leírását figyelembe véve az a második generációs dolomittípus — ,unimodális, változó szemcsenagyságú $(0,01-0,1 \mathrm{~mm})$ általában planáris szövetú dolomit, gyakran CCCR jelleggel" — része lehet.

A fentebb részletezett megfigyelések arra utalnak, hogy a finom-középkristályos planáris-s típusú dolomit már a diagenezistörténet igen korai szakaszában megjelenhetett. A kristályméretben, továbbá annak eloszlásában tapasztalt különbségek azonban többfázisú dolomitosodási folyamatokat sejtetnek. A rendelkezésre álló szöveti bizonyítékok alapján nem dönthető el egyértelmúen, hogy a finomközépkristályos planáris-s típusú dolomit csak a felszínközeli és sekély betemetődés tartományában, vagy a felszínközeli környezettől a közepes betemetődésig folyamatosan képződött (8. ábra).

A felszíni és felszín közeli — döntően tengervíz hatására végbement — dolomitosodási folyamatokat követően a betemetődési dolomitképződéshez ideális környezet $0,5-2 \mathrm{~km}$ mélységben, $50-60{ }^{\circ} \mathrm{C}$ körüli környezeti hőmérséklet mellett van (MACHEL 2004). Ennél nagyobb mélységekben már túlságosan korlátozott a fluidumok mozgása ahhoz, hogy nagyobb méretú kôzettesteket teljesen átható dolomitosodást okozzanak. Mivel a Szegedi-medence területén nem ismertek a középsô-triász és a középsô-miocén között keletkezett üledékek (BÉRCZINÉ 1986, HoRVÁTH Z. \& MAROS 2012), ezért a Békés-Codrui-egység más részeit, illetve a Villány-Bihariegység süllyedéstörténetét alapul véve valószínúsíthető, hogy a vizsgált képződmények a leülepedést követő süllye- désnek köszönhetően a középső-jura-alsó-kréta folyamán túlhaladhattak a közepes betemetődés ( 600-2000 m) zónáján és a késő-krétáig jelentősebb mélységbe süllyedhettek (Horváth A. 1990, HAAs \& Péró 2004). A triász képződmények kréta-paleogén során elért betemetődési mélységét jelzi, hogy több tanulmány (PóKA et al. 1987, NAGY et al. 2012, HATALYÁK 2002) szerint ekkorra már túlhaladtak az olajablakon $\left(>150{ }^{\circ} \mathrm{C}\right)$.

Az eddigieket összegezve valószínúsíthetô, hogy a középső-triász üledékképződést követően, a kora-juráig tartott a sekély betemetődés, ezt követően pedig legkésőbb a kora-krétáig a közepes betemetődés szakasza. A vizsgált képződmények jelentős része már a felszínközeli és sekély betemetődési diagenezis során dolomittá válhatott, de nem zárható ki, hogy ezek a folyamatok a közepes betemetődés tartományában is folytatódtak, aminek köszönhetően csaknem a teljes kőzettest átkristályosodott dolomittá.

\section{Közepes és mély betemetôdés I.}

Mikroszkópi megfigyeléseink alapján a diagenezistörténet következő állomását jelezheti a porfirotópos és cukorszövetû dolomit megjelenése. Ebbe a csoportba azokat a kőzeteket soroltuk, melyek minden esetben a már korábban kialakult szövetmegőrző dolomitot, a szövetromboló, finom-középkristályos planáris-s típusú dolomitot, illetve a vizsgált mészkőmintát bélyegzik felül. A szövet kialakulása általában közép-durva mérettartományba sorolható egyedi dolomitkristályok megjelenésével kezdődhetett. Az átkristályosodás során ez euhedrális, majd szubhedrális típusba ment át. Ebben a dolomitváltozatban egyaránt előfordulhatnak planáris és nem planáris kristályok, ami alapján leginkább a WRIGHT (2000) által javasolt átmeneti szövettípusba sorolhatjuk be. A közepes és durva kristályméret, valamint a nem planáris, unduláló kristályok megjelenése alapján valószínűsíthető, hogy ez a dolomittípus betemetődési környezetben, $50{ }^{\circ} \mathrm{C}$ feletti hőmérsékleten keletkezett helyettesítési dolomit (SIBLEY \& GREGG 1987). HoRVÁth A. (1990) nem különítette el önálló csoportként ezt a dolomitváltozatot, azt szintén a második generációs dolomittípusba sorolta. Megfigyeléseink szerint az oldódási üregek és repedések felé fokozatos átmenet észlelhető a cukorszövetú és a nyeregdolomit között, ami genetikai kapcsolatukra utalhat.

A közepes és mély betemetődési környezet jellemző képződményei a kémiai kompakció eredményeként létrejövő sztilolitok, melyek a többi szöveti elemhez való viszonyuk alapján szintén több fázisban képződhettek (8. ábra).

A repedéskitöltő dolomittípusok többsége szintén a közepes, illetve mély betemetődés zónájában keletkezhetett, azonban mivel az összlet fejlődéstörténetében két jelentős süllyedési fázis (középső-triász-kora-kréta és középső-miocén-holocén) és közöttük a késô-kréta-paleogén idején több, jelentős kiemelkedéssel és kisebb süllyedéssel járó periódus feltételezhetô (HAAS \& PÉRÓ 2004, HAAS et al. 2014c), ezért ezek időbeli elhelyezése bizonytalan.

A két különböző területről származó mintákat össze- 
hasonlítva a legszembetúnóbb különbség, hogy Üllésról szinte kizárólag repedezett dolomitot vagy dolomitbreccsát ismerünk, míg a vizsgált mórahalmi minták kevésbé töredezettek, csak a nagyobb mélységből származó kôzetek breccsásodtak. Ez összhangban van azzal, hogy jelen ismereteink szerint az üllési terület északnyugati részén húzódik a Békés-Codrui-takarórendszer áttolódási frontja (1. ábra; HAAs et al. 2010). A többszöri töréses deformáció hatásának köszönhetően számos repedéskitöltési generáció megfigyelhető, melyek közül csak azokat helyeztük el a paragenetikai sorrendben (8. ábra), melyek mindkét területen jól korrelálhatóak egymással.

A közepes és mély betemetődés során valószínúleg több szakaszban, nagy területre kiterjedôen zajlott olyan vetőmúködés, melynek következtében breccsa és kataklázit képződött. A breccsák tektonikus eredetét támasztja alá azok mozaikos szövete, illetve az, hogy a kataklázitokban a különböző mértékben lekerekedett klasztok térbeli eloszlása szabályszerúségeket mutat. Tektonikus eredet esetén a fokozatosan aprózódó klasztok alakja egyre nagyobb szögszámú poligonnal közelíthetô, így azok a vetôzónák közepén már teljesen lekerekítetté válhattak (STORTI et al. 2003).

Az intenzív breccsásodást követően fennmaradó vagy újonnan keletkező töréses és oldásos pórusokban nyeregdolomit kristályosodott ki (8. ábra). A nyeregdolomit kristályaiban gyakoriak a növekedési zónákhoz vagy a felhôs maghoz kapcsolódó kőolajtartalmú fluidumzárványegyüttesek. Amennyiben feltételezzük, hogy a hasonló tulajdonságokat mutató nyeregdolomitok nagyjából azonos időben és azonos körülmények között keletkeztek, akkor ezek kialakulása a középsô-miocén előttre tehetô, mivel ezt a repedéskitöltő típust megfigyeltük a miocén abráziós konglomerátum kavicsanyagában előforduló dolomitklasztokban is.

HoRVÁth A. (1990) a nyeregdolomitot „eltemetôdési”, „póruskitöltő dolomitcementként” írta le, amelynek képzôdése az intenzív breccsásodást követôen zajlott. Ez utóbbi megállapítását saját megfigyeléseink is megerősítik ( 8 . ábra).

\section{Kiemelkedéshez kapcsolódó képzódmények}

Miként a Tiszai-fóegység jelentős részén, a Szegedi-medence területén is hiányoznak, feltehetôen lepusztultak a felsôkréta-paleogén képződmények. A Szegedi Dolomit Formációra leggyakrabban középsô-miocén transzgressziós rétegsor települ, ami közvetlenül igazolja az azt megelőző felszíni kitettséget (BÉRCZINÉ MAKK et al. 2004, HAAS [ed.] 2013).

A felvázolt paragenetikai sorrend szerint (8. ábra) a nyeregdolomit által részlegesen kitöltött pórusok belsejében megjelenó ásványfázisok lehetnek azok, amelyek keletkezése telogenetikus környezetben, a képződmény újbóli kiemelkedésének idején történhetett. Ezek az ásványfázisok a reduktív környezetet jelzô sziderit és vasas kalcit, valamint különféle agyagásványok (részben biztosan kaolinit vagy dickit).

A nyeregdolomit kristályok visszaoldódása, és a vasas kalcit általi helyettesítése a dedolomitosodás folyamatát jelzi, amelyet okozhatott hidrotermás hatás, de ez a folyamat a felszínközeli, meteorikus-freatikus zónában is gyakori (FLÜGEL 2004). A sziderit gyakori cementtípus meteorikus vizekkel átjárt felszínközeli környezetben (MORAD et al. 2000), de hidrotermás eredete is lehetséges. Ásotthalom környéki mélyfúrásokban, metamorf kőzetekhez kapcsolódóan telogenetikus eredetú szideritet írtak le (FISER-NAGY et al. 2015), melynek kora és kialakulási körülményei hasonlóak lehettek az általunk megfigyelt szideritéhez. A különféle agyagásványok felszínközeli környezetben, sziliciklasztos üledékek mállása révén jönnek létre legnagyobb tömegben (MORAD et al. 2000), ahonnan esetleg bemosódással kerülhettek a középső-triász dolomit üregeibe. Azonban agyagásványok (pl. illit, kaolinit vagy dickit) hidrotermális úton, illetve vetők magzónájában is kialakulhatnak (ESTEBAN \& TABERNER 2003, StORTI et al. 2003). Mindezek alapján nem dönthetố el pontosan a vizsgált ásványok eredete, csupán a nyeregdolomitnál fiatalabb relatív koruk állapítható meg.

HoRvátH A. (1990) megemlíti, hogy a képződményben feltételezhető egy karsztosodási esemény. Ennek egyértelmú bizonyítékát nem találtuk meg, azonban a gyakran lekerekített klasztok, makroszkóposan is érzékelhető oldódásos felszínek, illetve az oldódási felszíneket és szideritcementet tartalmazó breccsák mátrixában nyomokban megjelenő sziliciklaszt utalhat ilyen folyamatokra (LOUCKs 2007).

\section{Közepes és mély betemetódés II.}

A miocéntől kezdődôen süllyedésnek indult a terület (TARI et al. 1999, M. TóTH 2008), aminek köszönhetően ismét a közepes majd a mély betemetôdés zónájába (>2000 m) kerültek a vizsgált kőzetek. A fázis korai szakaszában dominánsan lokális jelleggel — ismét mikrokristályos dolomittal cementált tektonikus breccsa és kataklázit keletkezett, de a nyeregdolomit keletkezésének lehetôségét sem tudjuk kizárni ebben a szakaszban. Ezt követően még legalább két fázisban átható töréses deformáció érte a kôzeteket (8. ábra). Ehhez kapcsolódva előbb víztiszta, érkitöltő pátos dolomit keletkezett, majd az ezt követően kialakult töréseket intenzív fluoreszenciát mutató dolomitból, szilárd bitumenből és piritkristályokból álló repedéskitöltő ásványtársulás töltötte ki. Ez a legfiatalabb repedéskitöltő ásványtársulás egy olyan törésgenerációhoz kapcsolható, mely szinte minden szöveti elemet felülbélyegez, és általánosan elterjedt a területen. HoRvÁtH A. (1990) szintén a legfiatalabb repedéskitöltési generációként írta le az intenzív fluoreszcenciát mutató dolomitereket. Hasonló tulajdonságú cementanyagot, valamint pirit és bitumen együttes jelenlétét figyeltük meg néhány középsố-miocén sziliciklasztos fedôkôzetben is, ami arra utalhat, hogy ez a generáció már akkor alakulhatott ki, amikor a triász dolomit és a miocén abráziós képződmények közös hidrológiai rendszert alkottak. A közepes és mély betemetôdés II. folyamán sem zárhatók ki több fázisban lejátszódó, nyomásoldódással és sztilolitképződéssel járó események, melyek oka a betemetődési rétegterhelés, vagy tektonikus stresszhatás lehetett. A felvázolt paragene- 
tikai sorrend (8. ábra) legfiatalabb képződményei ezek a sztilolitok, de a piritet és szilárd bitument tartalmazó fluoreszcens dolomiterekhez való viszonyuk gyakran bizonytalan.

\section{Szénhidrogénföldtani következtetések és a nyeregdolomit genetikája}

Viszonylag jelentôs szervesanyag-tartalma miatt felmerült annak lehetősége, hogy a Szegedi Dolomit Formáció anyakőzetként is számításba vehető a szénhidrogénrendszerben. Üllés környéki mintákon végzett vizsgálatok alapján PóKA et al. (1987) megállapították, hogy a középsőtriász képződmények jelenleg a száraz gáz zónájában találhatóak, kerogénjeik túlérettek. HoRvÁTH A. (1990) szerint az esetlegesen belőlük generálódott szénhidrogének a kréta-paleogén folyamán eltávoztak.

A Szegedi Dolomit Formáció szénhidrogénföldtani szempontból elsősorban repedezett tárolókőzetként vehető számításba (HoRVÁTH Z. \& MAROs 2012, KISS et al. 2015), amit saját megfigyeléseink is alátámasztanak. A mellékkőzetben az átkristályosodott dolomitokra jellemző kristálylapok közötti porozitás csak alárendelten figyelhetô meg (7. ábra), azonban a változó mértékben cementált repedések mellett számottevő lehet az oldódásos eredetú, csatornás és üreges, „vuggy” jellegú porozitás (5. ábra, c, I. tábla, 3. kép). A repedések, csatornák és üregek leggyakoribb kitöltő ásványa a nyeregdolomit, melynek jelenléte viszonylag magas hőmérsékletú (80-235 ${ }^{\circ} \mathrm{C}$ ) képződési környezetet jelez (RADKE \& MATHIS 1980, WARREN 2000). MACHEL \& LONNEE (2002) szerint képződése háromféle környezetben lehetséges: 1) advekciós áramlásokból, 2) korábbi dolomitok átkristályosodása révén és 3) termokémiai szulfátredukció melléktermékeként. Mivel a Szegedi Dolomit Formáció vizsgált mintáiban a nyeregdolomit elterjedése jellemzően olyan mintákhoz kapcsolódik, melyek intenzív töréses deformáción mentek keresztuil, és maga a nyeregdolomit is jellemzően repedéskitöltő cementként van jelen, ezért feltételezhető, hogy képződése áramló fluidumokhoz köthetô.

A nemzetközi szakirodalomban a nyeregdolomitot leggyakrabban az úgynevezett ,hidrotermás dolomit rezervoárokkal" kapcsolatosan említik (SMITH \& DAVIES 2006). Definíció szerint a hidrotermás dolomitosodás olyan kőzetátalakulás, melyet a befogadó kőzetnél magasabb hőmérsékletû fluidummal való reakció eredményez (MACHEL \& LONNEE 2002). Hazánk területén már több tanulmányban leírtak geotermikus hőmérsékletnek megfelelő körülmények között keletkezett nyeregdolomitot (HAAS et al. 2014a, b), de bizonyítottan hidrotermás eredetû keletkezése is ismert (Hips et al. 2015). Tehát a „hidrotermás” elnevezés alkalmazásához mindenképpen szükséges lenne a képződési körülmények pontosabb ismerete, ezek hiányában csupán lehetséges analógiaként tekinthetünk a hidrotermás dolomitrezervoárokkal foglalkozó szakirodalmakra. Ebben a rezervoártípusban jellemzően extenziós tektonikához kapcsolódó vetôk és oldalelmozdulások mentén feláramló magas hőmérsékletû fluidumok oldó hatásának következtében növekszik meg a kőzetek porozitása. Az így létrejövő pórustérben megjelenő leggyakoribb ásványtípus a nyeregdolomit, melyet további változatos ásványegyüttes kiválása követhet (pl. Mississippi Valley-típusú Pb-Zn ércesedések), de a pórustér megőrződése esetén ezek jelentős fluidumtároló potenciállal bírhatnak (ESTEBAN \& TABERNER 2003, DAVIES \& SMITH 2006). Általában igen komplex geokémiai és szerkezetföldtani vizsgálatok szükségesek az átalakult, nagy porozitású dolomittestek kiterjedésének és tárolókapacitásának előrejelzéséhez (DAVIES \& SMITH 2006).

Az általunk vizsgált minták esetében annyi állapítható meg nagy bizonyossággal, hogy viszonylag korai diagenetikus folyamatok révén a karbonátuiledékek, illetve -kőzetek valószínúleg teljesen dolomittá váltak. Ezt követően a dolomit kőzetet olyan hatások érték, melyek következtében törések mentén intenzív oldódás mehetett végbe, majd pedig nyeregdolomit vált ki. Kutatásaink további célját képezi, hogy pontosabb képet kapjunk a nyeregdolomitot létrehozó folyamatokról. Ezek ismeretében nagyobb biztonsággal lehetne előre jelezni a megnövekedett porozitású dolomittestek elterjedését. Az ilyen irányú új ismeretek a medence hőtörténeti modelljének is fontos részét képezhetnék.

Megfigyeléseink alapján a nyeregdolomit egy részének már a középső-miocén eróziós folyamatokat megelőzően ki kellett alakulnia, mivel lepusztulási termékként megtalálható az ilyen korú üledékekben. Tekintettel arra, hogy a fentiekben felvázolt képződési feltételek többször is fennállhattak a medence fejlődéstörténete folyamán, így nem zárható ki egy fiatalabb képződési fázis sem (8. ábra).

Szénhidrogénföldtani szempontból további jelentőséggel bírnak a nyeregdolomit kristályokban csapdázódott kőolajtartalmú elsődleges fluidumzárványok. Ezen olajzárványok anyaga származhat a mellékkőzet kerogénjeinek termikus éréséből, vagy jelezhetik azt, hogy egy, a medence más anyakőzetéből generálódott szénhidrogén migrált, illetve tárolódott a pórustérben a nyeregdolomit kristályosodásának idején. A csapdázott szénhidrogének eredetének pontosítása további részletes szerves geokémiai vizsgálatokat igényel.

A fiatal érkitöltésekben kristálylapok között megjelenô, valamint a sztilolitok egy részéhez kapcsolódó szabálytalan, kristályszerkezet nélküli, opak szervesanyag feltehetően szilárd bitumen. A szilárd bitumenek többnyire nagy molekulatömegú szénhidrogének (policiklusos aromás szénhidrogének, aszfaltének, karbonsavak stb.) keverékei. Szilárd bitumen kialakulhat az anyakőzetekben kőolajképződés melléktermékeként, illetve a szénhidrogén migrációja során úgynevezett rezervoár bitumen formájában (SUÁREZ-RUIZ 2012). A vizsgált mintákban a legtöbb esetben repedésekhez, illetve sztilolitokhoz kapcsolódik a bitumen, melyek feltehetôen az egykori migrációs útvonalat vagy a tárolóporozitást jelzik.

\section{Összefoglaló következtetések}

A Szegedi Dolomit Formáció vizsgált képződményei változatos partszegélyi, sekélytengeri környezetben ülepedtek le. Eredményeink alapján leggyakoribbak a különböző szupra- és intertidális, valamint mozgatott vízi biogén karbo- 
náthomok mikrofáciesek, azaz megerősíthetôek HoRváTH A. (1990) leülepedési környezetre tett megállapításai. A felszínközeli és sekély eltemetôdési környezetben végbement diagenetikus folyamatok magukba foglalják a tengeri freatikus cement kiválását, a mikritesedést, a kiemelt helyzethez köthető édesvízi vadózus és freatikus kioldódást és póruskitöltő cementképződést, valamint nagy valószínúséggel a dolomitosodási folyamatok számottevő részét.

Értelmezésünk szerint többféle dolomitosodást okozó folyamat feltételezhetô, de ezek pontos elkülönítése további, szöveti alapon végzett stabilizotóp-geokémiai vizsgálatokat igényel. A petrográfiai alapon elkülönített dolomittípusok közül már biztosan közepes vagy mély betemetôdési környezetet jeleznek a porfirotópos és cukorszövetú dolomitok, valamint a póruskitöltő nyeregdolomit, de ezek szerepe alárendelt a korábbi dolomitosodási folyamatokhoz viszonyítva.

A többfázisú betemetődési és kiemelkedési események során többszöri töréses deformáció érte a kôzeteket, aminek következtében az összlet meghatározó része (különösen Üllés környékén) tektonitnak minősíthetô. A betemetôdési szakaszokhoz kapcsolható nyeregdolomit regionális előfordulása miatt felvetődik a kérdés, hogy az egyes minták egymással hogyan korrelálhatóak. Mivel a nyeregdolomit képződéséhez jelentôs másodlagos porozitás-növekedés kapcsolható, ezért a kialakító folyamatok pontosítása rezervoárgeológiai szempontból is fontos. Ezen kérdések megválaszolásához további részletes vizsgálatok elvégzésére van szükség. A középsômiocénnél mindenképpen fiatalabb szénhidrogén-migrációs eseményeket jeleznek a fluoreszcens dolomittípushoz kapcsolódó pirit és szilárd bitumennyomok.
Az alkalmazott módszereknek köszönhetően számos esetben igazoltuk a tektonitok jelenlétét és a töredezettség magas fokát olyan kôzetekben, ahol ez az előzetes leírások és a hagyományos mikroszkópi vizsgálatok alapján sem volt egyértelmú. Így valószínúsíthetô, hogy a régi kútkönyvi leírásokra épülô rétegoszlopokban, földtani szelvényeken a tektonitok általában alulreprezentáltak. Mindez felveti egy szerkezetföldtani felülvizsgálat szükségességét a területen.

\section{Köszönetnyilvánítás}

A kutatás különböző fázisaiban (mintagyújtés, szakmai konzultáció) nyújtott segítségéért Dr. Kiss Balázsnak (MOL Nyrt.) mondunk köszönetet. Köszönet illeti továbbá Dr. M. TóTH Tivadart (SZTE Ásványtani, Geokémiai és Kőzettani Tanszék) a munkánk elkészítéséhez szükséges feltételek biztosításáért. Köszönetünket fejezzük ki SzUROMINÉ KORECZ Andreának mikropaleontológiai vizsgálatok elvégzéséért. SzIGETI Máté és BENCSIK Attila a vékonycsiszolatok elkészítésekor volt pótolhatatlan segítségünkre. Köszönettel tartozunk Dr. MindSZENTY Andreának és Dr. HAAS Jánosnak a kézirat bírálata során végzett munkájukért.

A Szegedi Dolomit Formáció reambulációja az SZTE Földtudományi Doktori Iskola keretein belül folyó PhD téma részét képezi (GARAguly István). Ez a munka a Nemzeti Kutatási, Fejlesztési és Innovációs Alap (korábban OTKA) K 108375 nyilvántartási számú témája keretében (vezetô kutató: RAUCSIKNÉ VARGA Andrea), valamint a MOL Nyrt. támogatásával készült.

\section{Irodalom — References}

BÉRCZINÉ MAKK A. 1986: Mesozoic formation types of the Great Hungarian Plain. — Acta Geologica Hungarica 29/3-4, 261-282.

BÉRCZINÉ MAKK A. 1998: Az Alföld és a Tokaji-hegység triász és jura képződményeinek rétegtana. — In: BÉRCZI I. \& JÁMBOR Á. (szerk.): Magyarország geológiai képzódményeinek rétegtana. — MOL-MAFI, Budapest, 281-298.

BérczinÉ MaKk A., Konrád Gy., RÁlischné Felgenhauer E. \& TöröK Á. 2004: Tiszai Egység. — In: HaAs J. (szerk.): Magyarország geológiája, Triász. - Eötvös Kiadó, Budapest, 303-354.

Bons, P. D. 2000: The formation of veins and their microstructures. - Journal of the Virtual Explorer 2, p. 12 (http://dx.doi.org/ 10.3809/jvirtex.2000.00007)

DAVIES, G. R. \& SMith, L. B. JR. 2006: Structurally controlled hydrothermal dolomite reservoirs facies: an overview. - AAPG Bulletin 90, 1641-1690. (http://dx.doi.org/10.1306/05220605164)

Dickson, J. A. D. 1966: Carbonate identification and genesis as revealed by staining. — Journal of Sedimentary Research 36, $491-505$. (http://dx.doi.org/10.1306/74d714f6-2b21-11d7-8648000102c1865d)

DunHAM, R. J. 1962: Classification of carbonate rocks according to their depositional texture. — In: HAM, W. E. (ed): Classification of Carbonate Rocks. - AAPG Memoir 1, 108-121.

EstebAn, M. \& TABERnER, C. 2003: Secondary porosity development during late burial in carbonate reservoirs as a result of mixing and/or cooling of brines. - Journal of Geochemical Exploration 78, 355-359. (http://dx.doi.org/10.1016/S0375-6742(03)00111-0)

Fiser-Nagy Á., MéSZÁros E., VARGa A., M. Tóth T. \& SchUbert F. 2015: Az Ásotthalom környéki metamorf aljzat kőzettani felépítése és átalakulási folyamatai. - Meddig ér a takarónk? A magmaképzódéstól a regionális litoszféra formáló folyamatokig: 6. Kózzettani és geokémiai vándorgyúlés, Ópálos (Paulis), Románia, 47-50.

FLÜGEL, E. 2004: Microfacies of Carbonate Rocks, Analysis. Interpretation and Application. — Springer-Verlag, Berlin, Heidelberg, 924 p. (http://dx.doi.org/10.1007/978-3-662-08726-8)

GREGG, J. M. \& SiBLEY D. F. 1984: Epigenetic dolomitization and the origin of xenotopic dolomite texture. — Journal of Sedimentary Petrology 54, 908-931. (http://dx.doi.org/10.1306/212f8a35-2b24-11d7-8648000102c1865d)

HAAs, J. 1998: Karbonátszedimentológia. —ELTE Eötvös kiadó, Budapest, 147 p.

HAAS, J. (ed) 2013: Geology of Hungary. — Eötvös University Press, Budapest, 246 p. (http://dx.doi.org/10.1007/978-3-642-21910-8)

HAAs J. \& PÉRó Cs. 2004: Mesozoic evolution of the Tisza Mega-unit. — International Journal of Earth Sciences 93, $297-313$. (http://dx.doi.org/10.1007/s00531-004-0384-9) 
HaAs J., Budai T., Csontos L., Fodor L. \& KonRád Gy. 2010: Magyarország pre-kainozoos földtani térképe, 1:500 000. — Magyar Állami Földtani Intézet kiadványa, Budapest

HaAs, J., Budai, T., Győri, O. \& Kele, S. 2014a: Multiphase partial and selective dolomitization of Carnian reef limestone (Transdanubian Range, Hungary). — Sedimentology 61, 836-859. (http://dx.doi.org/10.1111/sed.12088)

HAAS, J., BUdAI, T., GYŐRI, O. \& KELE, S. 2014b: Similarities and differences in the dolomitization history of two coeval Middle Triassic carbonate platforms, Balaton Highland, Hungary. — Facies 60, 581-602. (http://dx.doi.org/10.1007/s 10347-014-0397-1)

HAAs J., BudAi T., CsONTOS L., FodOR L., KonRÁD Gy. \& KoROKNAI B. 2014c: Magyarország prekainozoos medencealjzatának földtana. Magyarázó „Magyarország pre-kainozoos földtani térképéhez”(1:500 000). — Magyar Földtani és Geofizikai Intézet, Budapest, 71 p.

HATAlYÁK, P. 2002: A Duna-Tisza köze középső részének mezozóos-kainozóos süllyedés- és éréstörténetének kétdimenziós modellezése. - Diplomamunka, Budapest, $115 \mathrm{p}$.

HIPS K., HAAS J. \& GYŐRI O. 2015: Hydrothermal dolomitization of basinal deposits controlled by a synsedimentary fault system in Triassic extensional setting, Hungary. — International Journal of Earth Sciences 105, 1215-1231. (http://dx.doi.org/10.1007/s00531-015-12374)

HoRváTH A.1990: Szedimentáció- és diagenezis vizsgálatok D-alföldi szénhidrogénkutató fúrások anizuszi dolomit (Szegedi terület) és nagyharsányi mészkő (Bácskai terület) képződményein. - Doktori értekezés, kézirat, ELTE, Budapest, 107 p.

HoRVÁTH I. 2003: A Szeged környéki szénhidrogénelőfordulások felkutatásának, feltárásának és termeltetésének tapasztalatai. — Köolaj és Földgáz 36 (136)/7-8, 85-95.

Horváth Z. \& MARos Gy. (szerk.) 2012: Szegedi-medence szénhidrogén koncessziós terület: Komplex érzékenységi és terhelhetőségi vizsgálati tanulmány. - ELGI-MÁFI-MBFH-NeKI jelentés, Budapest, 182 p.

JuHÁsz Gy. 1992: A pannóniai (s.1.) formációk térképezése az Alföldön: elterjedés, fácies és üledékes környezet. — Földtani Közlöny 122, 133-165.

JUHÁSz Gy. 1998: A magyarországi neogén mélymedencék pannóniai képződményeinek litosztratigráfiája. — In: BÉRCZI I. \& JÁMBOR Á. (szerk.): Magyarország geológiai képzódményeinek rétegtana. — MOL Rt., MÁFI, Budapest, 469-484.

KISS, K., HorváTH, Zs. \& KISS, B. 2015: Szia TISIA, avagy miért szeretjük a Szegedi-medencét? — In: DÁLYAY V. \& SÁMSON M. (szerk.): Tisia konferencia kiadványa. 51-53.

LouCKs, R. G. 2007: A review of coalesced, collapsed-paleocave systems and associated suprastratal deformation. - Acta Carsologica 36/1, 121-132. (http://dx.doi.org/10.3986/ac.v36i1.214)

MACHEL, H. G. 1999: Effects of groundwater flow on mineral diagenesis, with emphasis on carbonate aquifers. — Hydrogeology Journal 7. $94-107$. (http://dx.doi.org/10.1007/s100400050182)

Machel, H. G. 2004: Concepts and models of dolomitization: a critical reappraisal. — In: Braithwaite, C. J. R., RizzI, G. \& Darke,G. (eds) The Geometry and Petrogenesis of Dolomite Hydrocarbon Reservoirs. - Geol. Soc. London Spec. Publ. 235, 7-63. (http://dx.doi.org/10.1144/GSL.SP.2004.235.01.02)

MACHEL, H. G. \& LONNEE J. 2002: Hydrothermal dolomite - a product of poor definition and imagination. - Sedimentary Geology 152, 163-171. (http://dx.doi.org/10.1016/S0037-0738(02)00259-2)

Matenco, L. \& RAdivojević, D. 2012: On the formation and evolution of the Pannonian Basin: Constraints derived from the structure of the junction area between the Carpathians and the Dinarides. - Tectonics 31, (TC6007), 31. (http://dx.doi.org/10.1029/ 2012TC003206)

Morad, S., Ketzer, J. M. \& De Ros, L. F. 2000: Spatial and temporal distribution of diagenetic alterations in siliciclastic rocks: implications for mass transfer in sedimentary basins. - Sedimentology 47, 95-120. (http://dx.doi.org/10.1046/j.1365-3091. 2000.00007.x)

M. TóTH T. 2008: Repedezett, metamorf fluidumtárolók az Alföld aljzatában. — MTA Doktori értekezés, Szeged, 399 p.

Nagy, Zs., Pogácsás, Gy., Juhász, Gy., Hatalyák, P., Milota, K., Csizmeg, J., Laukó, Á. \& Gombos, Cs. 2012: Calculation of unconformity related eroded stratal thicknesses along the Mid-Hungarian Mobile Belt in the Danube-Tisza interfluve area, Hungary. — Geosciences and Engineering: A publication of the University of Miskolc 1(2), 117-122.

Passchier, C. W. \& Trouw, R. A. J. 2005: Microtectonics — Springer, 366 p. (http://dx.doi.org/10.1007/978-3-662-08734-3)

PigotT, J. D. \& Radivojević, D. 2010: Seismic Stratigraphy Based Chronostratigraphy (SSBC) of the Serbian Banat Region of the Pannonian Basin. - Central European Journal of Geosciences 2/4, 481-500. (http://dx.doi.org/10.2478/v10085-010-0027-2)

Póka, T., Árkai, P., SAjgó, Cs., Horváth, Z. A., Tóth, M. N. \& VölgYi, L. 1987: Thermal history of Mesozoic basement in Pannonian Basin (S-Hungary). - Acta Geologica Hungarica 30/1-2, 197-229.

Radivojević, D., Rundić, L. \& KNEŽEvić, S. 2010: Geology of the Čoka structure in northern Banat (Central Paratethys, Serbia). Geologica Carpathica 61/4, 341-352. (http://dx.doi.org/10.2478/v10096-010-0020-5)

RADKE, B. M. \& MATHIS, R. L. 1980: On the formation and occurrence of saddle dolomite. - Journal of Sedimentary Petrology 50/4, 1149-1168. (http://dx.doi.org/10.1306/212f7b9e-2b24-11d7-8648000102c1865d)

RANDAZZO, A. F. \& ZACHOS, L. G. 1984: Classification and description of dolomitic fabrics of rocks from the Floridan aquifer, USA. Sedimentary Geology 37, 151-162. (http://dx.doi.org/10.1016/0037-0738(84)90005-8)

READ J. F. 1985: Carbonate Platform Facies Models — AAPG Bulletin 69/1, 1-21. (http://dx.doi.org/10.1306/ad461b79-16f7-11d7$8645000102 \mathrm{c} 1865 \mathrm{~d})$

Schmid, S. M., Bernouldi, D., Fügenschuh, B., Matenco, L., Schefer, S., Schuster, R., Tischler, M. \& Ustaszewski K. 2008: The Alpine-Carpathian-Dinaridic orogenic system: Correlation and evolution of tectonic units. — Swiss Journal of Geosciences 101/1, 139-183. (http://dx.doi.org/10.1007/s00015-008-1247-3)

Sibley, D. F. \& GRegG, J. M. 1987: Classification of dolomite rock textures. — Journal of Sedimentary Petrology 57, 967-975. (http://dx.doi.org/10.1306/212f8cba-2b24-11d7-8648000102c1865d)

SibSON, R. H. 1977: Fault rocks and fault mechanisms. - Journal of Geological Society London 133, 191-213. (http://dx.doi.org/ 10.1144/gsjgs.133.3.0191)

SMith, L. B. JR. \& DAVIES, G. R. 2006: Structurally controlled hydrothermal alteration of carbonate reservoirs: introduction. — AAPG Bulletin 90, 1635-1640. (http://dx.doi.org/10.1306/intro901106)

Storti, F., Billi, A., SAlvini, F. 2003: Particle size distributions in natural carbonate fault rocks: insights for non-self-similar cataclasis. — Earth and Planetary Science Letters 206, 173-186 (http://dx.doi.org/10.1016/S0012-821X(02)01077-4) 
SuÁrez-Ruiz, I. 2012: Organic Petrology: An Overview — In: AlJubory, A. (ed.): Petrology-New Perspectives and Applications, 199_ 224. (http://dx.doi.org/10.5772/23431)

Tari, G., Dövényi, P., Dunkl, I., Horváth, F., Lenkey, L., Stefanescu, M., Szafián, P. \& Tóth, T. 1999: Lithospheric structure of the Pannonian basin derived from seismic, gravity and geothermal data.- In: Durand, B., Jolivet, L., Horváth, F., SÉrAnNe, M. (eds): The Mediterranean Basins: Tertiary Extension within the Alpine Orogen. _ Geological Society, London, Special Publications 156, 215-250. (http://dx.doi.org/10.1144/gsl.sp.1999.156.01.12)

WARREN, J. K. 2000: Dolomite: occurrence, evolution and economically important associations. — Earth-Science Reviews 52, 1-81. (http://dx.doi.org/10.1016/s0012-8252(00)00022-2)

WiLson, J. L. 1975: Carbonate Facies in Geologic History. — Springer-Verlag, Berlin, 471 p. (http://dx.doi.org/10.1007/978-1-46126383-8)

Woodcock, N. H. \& Mort, K. 2008: Classification of fault breccias and related fault rocks. — Geological Magazine 145, 435-440. (http://dx.doi.org/https://doi.org/10.1017/S0016756808004883)

Wright, W. R., Johnson, A. W., Schelton, K. L., Somerville, I. D., GregG, J. M. 2000: Fluid migration and rock interactions during dolomitsation of the Dinantian Irish Midlands and Dublin Basin. - Journal of Geochemical Exploration 69-70, 159-164. (http://dx.doi.org/10.1016/s0375-6742(00)00019-4)

Kézirat beérkezett: 2016. 06. 16.

\section{I. tábla - Plate I}

A Szegedi Dolomit Formáció jellegzetes kézipéldányai

1) Sötétebb és világosabb szürke, közel párhuzamos sávokból (nyilak) álló sztromatolitos dolomit; 2) Fehér pátos dolomittal cementált mozaikos breccsa; 3 ) Oldódásos üreg falán fennőtt nyeregdolomit kristályok; 4) Dolomit breccsa többgenerációs dolomiterekkel (Dol1, Dol2), és sziderit kitöltésekkel (Sid); 5) Homogén szemcsevázú dolomitbreccsa, néhány centiméteres kataklázitos sávval (Cat); 6) Az 5. képen kijelölt kataklázitos szövet részletesebb képe, melyen a sárga számok különböző koptatottsági fokú klasztokat jelölnek; 7) Mátrixvázú dolomitbreccsa lekerekített klasztokkal, agyagos-sziderites mátrixanyaggal és piritkristályokkal (Py); 8) Vastag héjú kagylófosszilia

Characteristic hand specimens of Szeged Dolomite Formation

1) Stromatolitic dolomite composed by dark and white parallel bands (arrows); 2) Mosaic dolomite breccia cemented by white sparry dolomite; 3) Dissolution vug partially filled by saddle dolomite; 4) Dolomite breccia with polyphase dolomite veins (Doll, Dol2) and siderite (Sid) cement; 5) Clast-supported dolomite breccia with cataclasite band (Cat); 6) A detail of cataclastic fabric shown in 5. Yellow numbers represent clasts with different degree of surface abrasion; 7) Matrix-supported breccia with rounded clasts cemented by siderite, clay minerals, and pyrite (Py); 8) Thick walled bivalve shell

\section{II. tábla - Plate II}

Az üllési dolomitbreccsák és erek jellemző cementtípusai

1) Kora-diagenetikus átkristályosodott repedés (sárga nyilak) és a mellékkőzet planáris-s típusú finomkristályos dolomitja; 2) Tektonikus eredetủ dolomitbreccsa mikrites dolomitcementtel; 3) Üregkitöltő, enyhén görbült kristálylapú nyeregdolomit (SD), valamint pórusteret elzáró agyagásványok (Clay); 4) Repedéskitöltő, erősen torzult kristálylapokkal határolt, „, barokk” vagy nyeregdolomit, „dárdahegy” alakú kristályokkal; 5) Viztiszta, pátos dolomitér másodlagos fluidumzárvány együttessel (piros nyilak); 6) Opak pirittel, bitumennel, valamint pátos dolomittal kitöltött erek (piros nyilak); 7) Korai diagenetikus sztilolitok (sárga nyilak), melyet fiatalabb nyeregdolomittal kitöltött repedések harántolnak; 8) Breccsa klasztjai között áthatoló, kései diagenetikus sztilolit (sárga nyilak)

Typical cements of breccias and veins collected from Üllés area

1) Recrystallized early diagenetic vein (yellow arrows) and host dolostone composed of finely crystalline planar-s type dolomite; 2) Fault breccia consists of dolomite clasts and cemented by micritic dolomite; 3) Pore filling saddle dolomite (SD) with slightly curved crystal faces and pore-occluding clay minerals (Clay); 4) Vein filling saddle or baroque dolomite with strongly deformed crystal faces and spear-forms; 5) White sparry dolomite vein with secondary fuid inclusion assemblege (red arrows); 6) Veins filled by sparry dolomite, opaque pyrite and bitumen (red arrows); 7) Early diagenetic stylolites (yellow arrows) cross-cutted by saddle dolomite veins (SD); 8) Breccia fabric crossed by late diagenetic stylolite (yellow arrows)

\section{III. tábla - Plate III}

Jellegzetes cementtípusok normál áteső (1N) és fluoreszcens mikroszkópi képe (Fluo)

1a) és b) Fluoreszkáló pátos dolomittal, bitumennel és pirittel kitöltött repedés; 2a) és b) Peloidos dolomit kőzet rejtett breccsás szövettel. A nyilak ugyanarra a pontra mutatnak; 3a) és b) Mikritburokkal körbevett peloid; 4a) és b) Nyeregdolomit növekedési zónájában csapdázódott elsődleges olajzárványok Photomicrographs (1N) and fluorescence images (Fluo) of the characteristic cement phases

la) and b) Sparry fluorescent dolomite veins with bitumen and pyrite; 2a) and b) Peloidal dolostone with hidden breccia fabric. Arrows show to the same point; $3 a$ ) and $b$ ) Peloid with micritic envelope; 4a) and b) Primary petroleum inclusions trapped in growth face of saddle dolomite

\section{IV. tábla - Plate IV}

Jellegzetes cementtípusok normál áteső (1N) és katódlumineszcens (CL) mikroszkópi képe (CL)

1a) és b) Zónás nyeregdolomit, tompa és élénken lumineszkáló zónákkal, valamint szilárd zárványokkal; 2a) és b) Víztiszta pátos dolomitér nem lumineszkáló dolomitfázisának kristálylapjai között negatív kristályformát felvevő másodlagos dolomitcementtel; 3a) és b) Polimikt, kaotikus szövetű breccsa rejtett szövettel. A nyilak ugyanazokra a pontokra mutatnak; 4a és b) Szemcse lumineszkáló mikrites bekérgezéssel

Photomicrographs (IN) and cathodoluminescence (CL) images of the characteristic cement phases

$1 a$ and b) Zoned saddle dolomite crystal showing dull and bright luminescent zones and solid inclusions; 2) White sparry non-luminescent dolomite vein contains secondary bright luminescent negative crystal shape dolomite phase; 3) Polymictic, chaotic breccia with hidden fabric. Arrows show to the same points; 4) Grain with luminescent micritic envelope 
I. tábla - Plate I
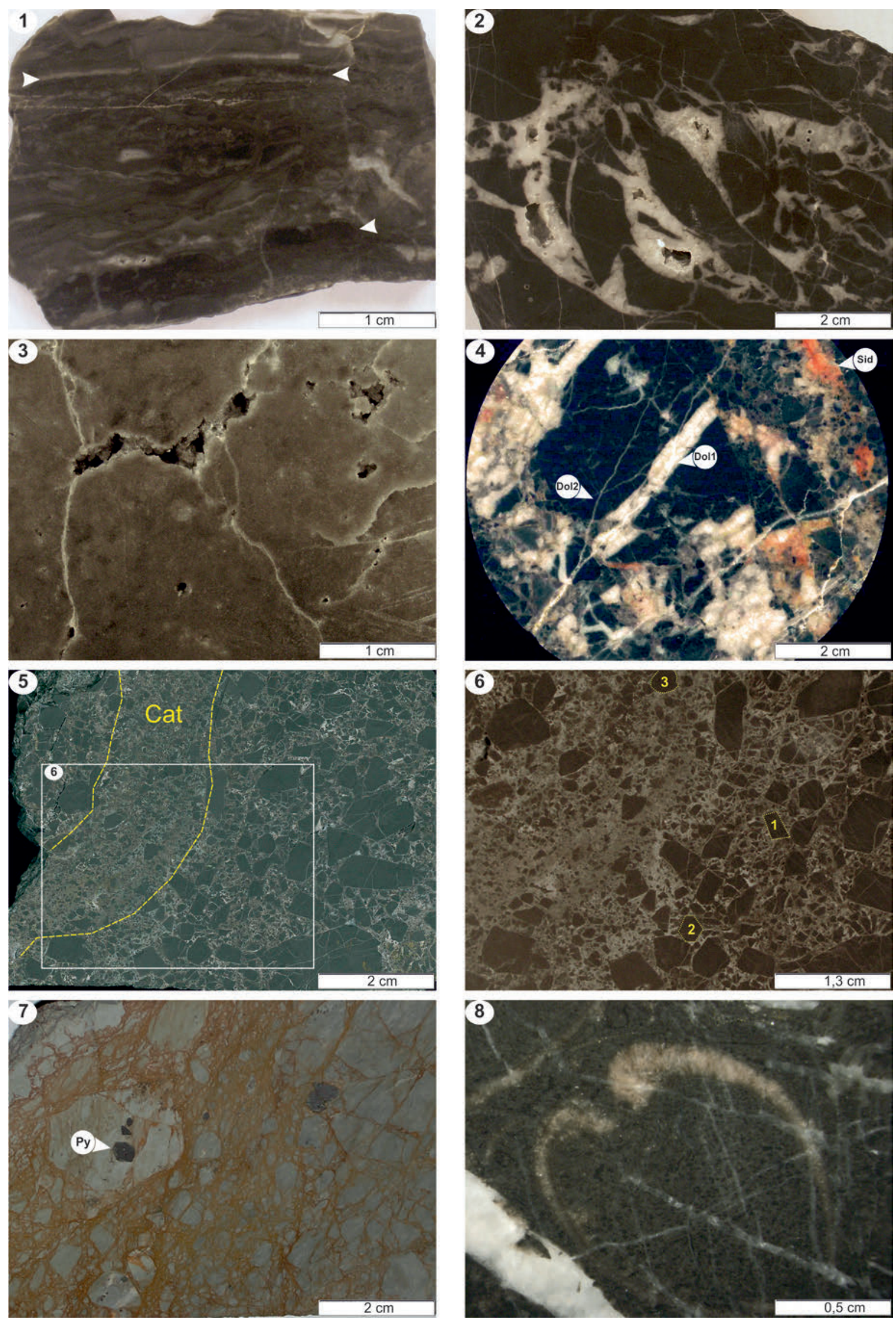


\section{II. tábla - Plate II}
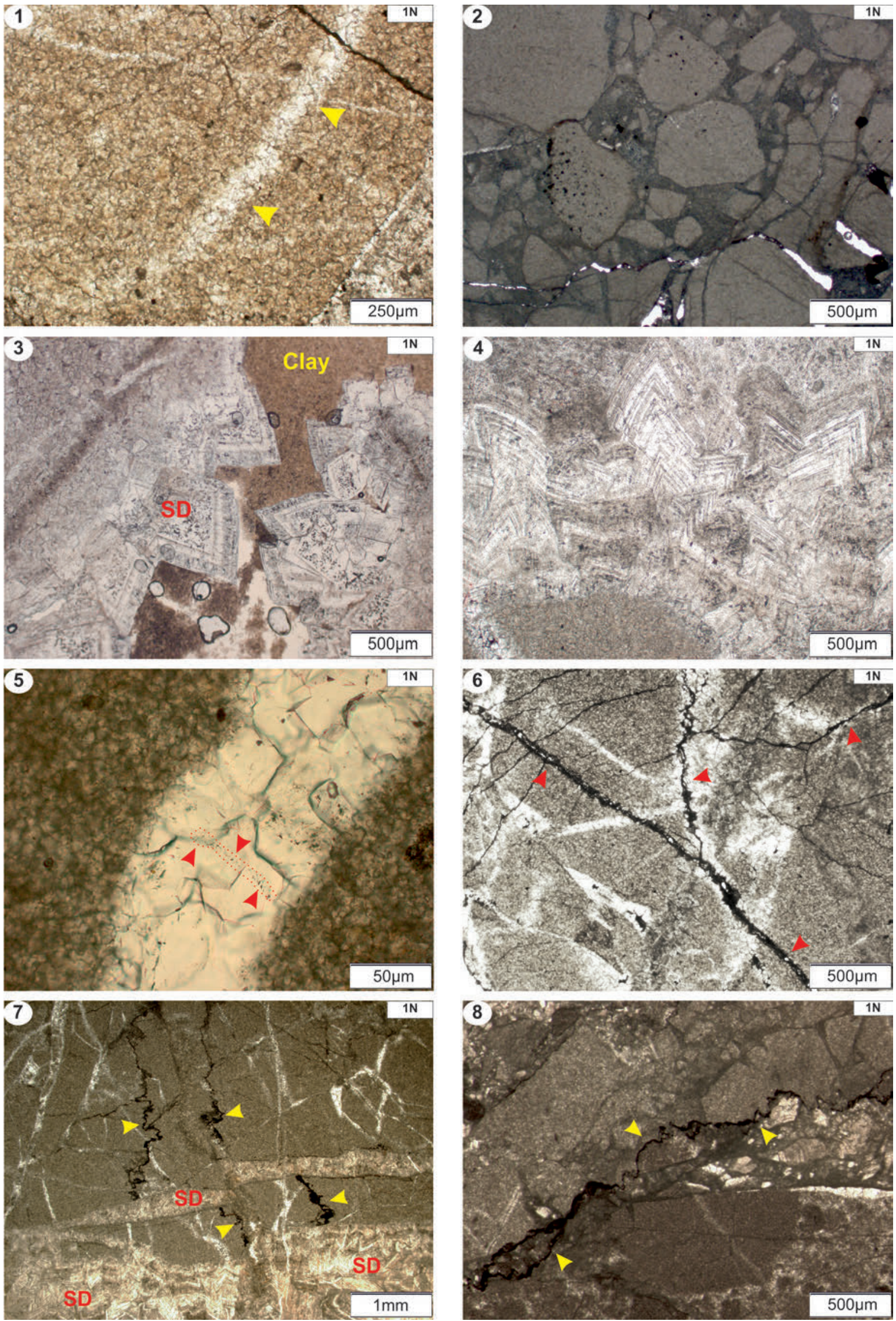


\section{III. tábla — Plate III}
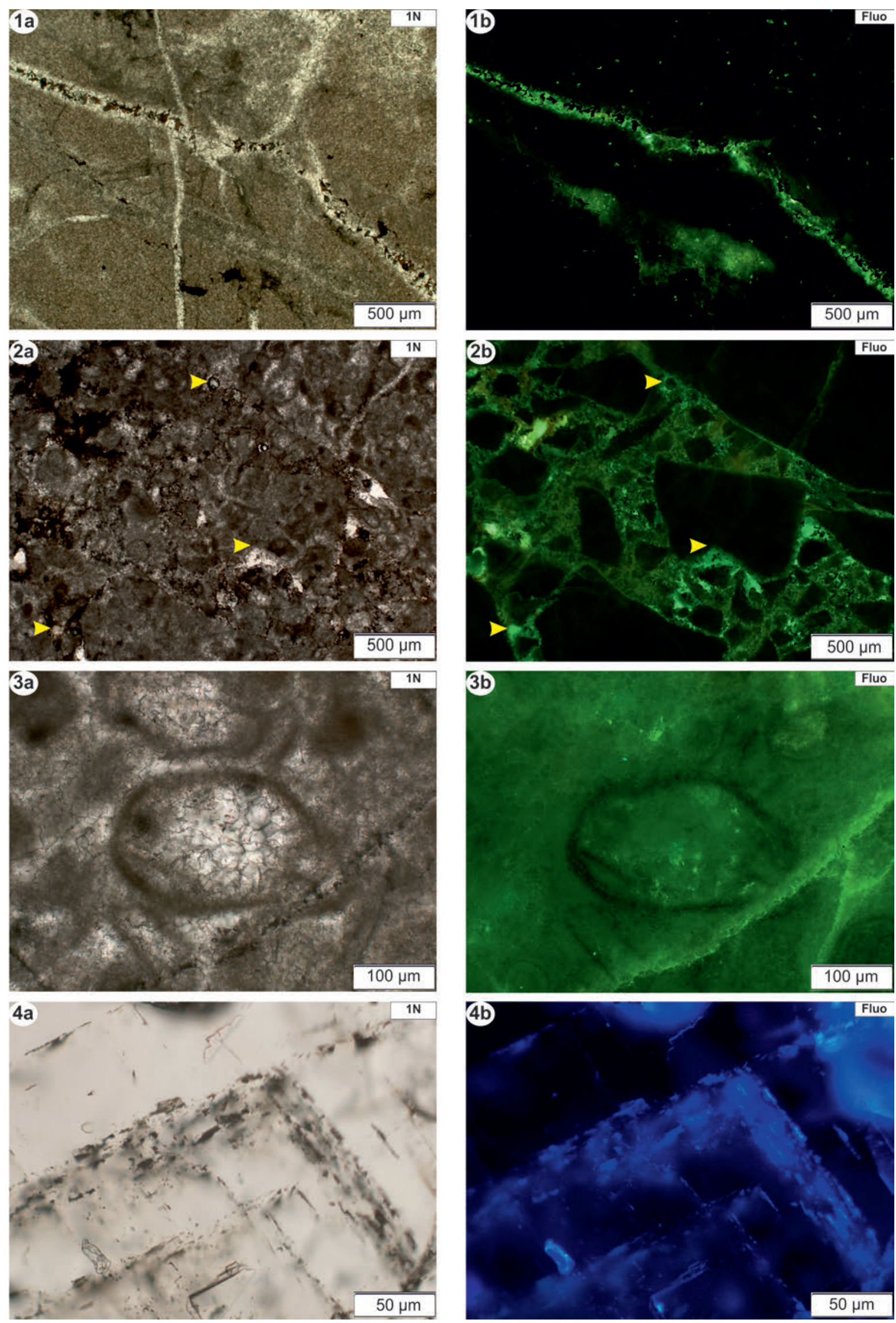


\section{IV. tábla - Plate IV}
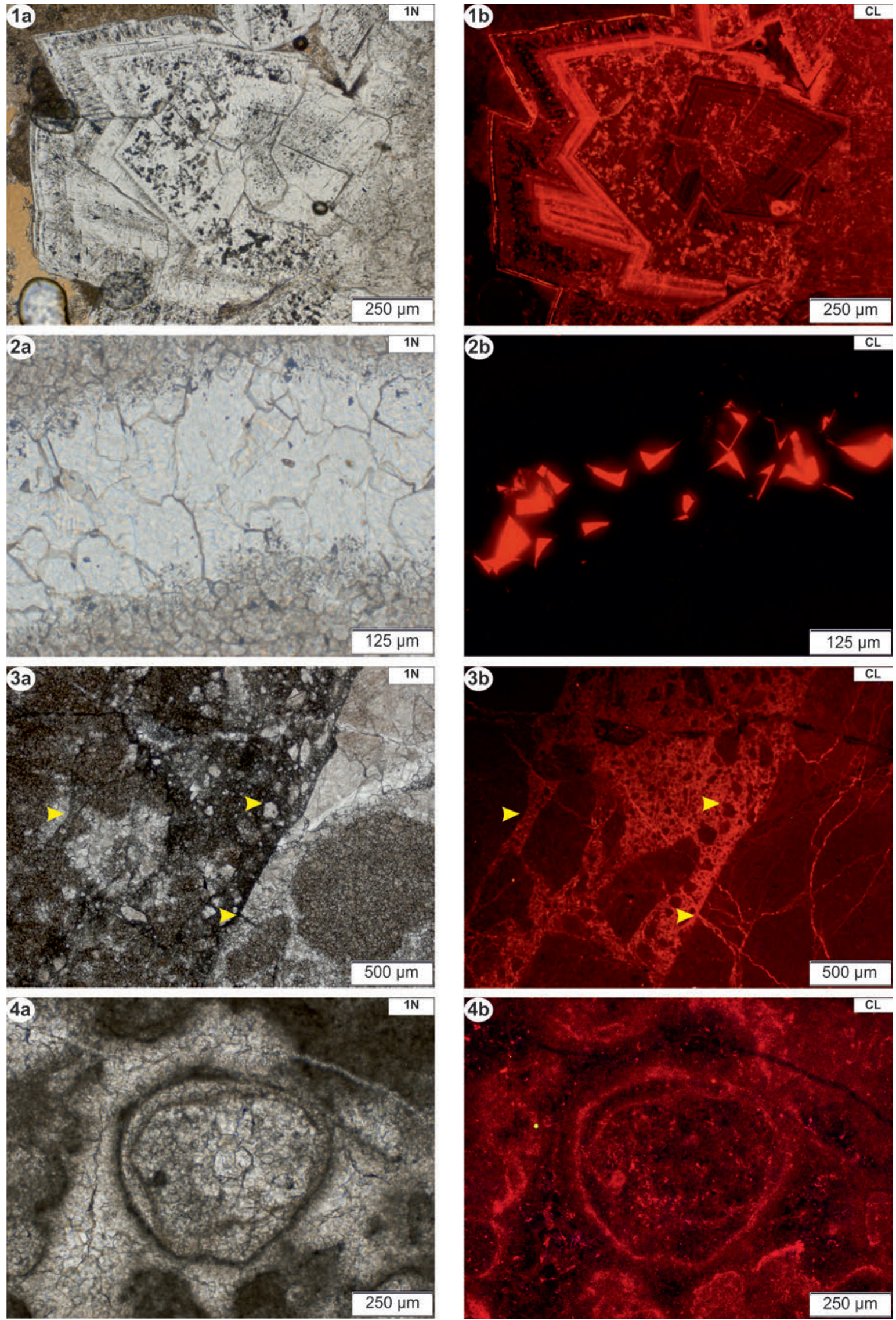